Article

\title{
Land-Use/Landscape Pattern Changes and Related Environmental Driving Forces in a Dong Ethnic Minority Village in Southwestern China
}

\author{
Fanya Qin ${ }^{1}$, Katsue Fukamachi ${ }^{1,2}$ and Shozo Shibata ${ }^{1,2, *(D)}$ \\ 1 Laboratory of Landscape Ecology and Planning, Kyoto University, Kyoto 606-8501, Japan; \\ qin.fanya.52n@st.kyoto-u.ac.jp (F.Q.); hukamachi.katsue.2e@kyoto-u.ac.jp (K.F.) \\ 2 Laboratory of Landscape Architecture, Kyoto University, Kyoto 606-8501, Japan \\ * Correspondence: shibata.shozo.6n@kyoto-u.ac.jp; Tel.: +81-75-753-6084
}

check for

updates

Citation: Qin, F.; Fukamachi, K.; Shibata, S. Land-Use/Landscape Pattern Changes and Related Environmental Driving Forces in a Dong Ethnic Minority Village in Southwestern China. Land 2022, 11 349. https://doi.org/10.3390/ land11030349

Academic Editors

Antonio Gómez-Sal and

Asunción Saldaña-López

Received: 9 January 2022

Accepted: 24 February 2022

Published: 27 February 2022

Publisher's Note: MDPI stays neutral with regard to jurisdictional claims in published maps and institutional affiliations.

Copyright: (C) 2022 by the authors. Licensee MDPI, Basel, Switzerland. This article is an open access article distributed under the terms and conditions of the Creative Commons Attribution (CC BY) license (https:// creativecommons.org/licenses/by/ $4.0 /)$.

\begin{abstract}
This paper outlines land-use/landscape pattern changes and relationships between landuse change trajectories and environmental variables in the Dong ethnic-minority village of Gaoyou in southwestern China. In the study, landscape metrics were applied to evaluate changes in land use and landscape patterns using GeoEye-1 satellite imagery for 2009/2020 and drone imagery for 2019, and redundancy analysis (RDA) was applied to clarify the relationship between land-use change trajectories and environmental variables. The $10-30 \%$ change in land use observed across each time sequence indicated rapid development in the area, resulting in increased fragmentation and reduced aggregation. The findings showed efficient usage of land resources in Gaoyou. Accessibility to land tended to govern the characteristics of land-use change, with natural variables influencing the type of development. The results also indicated that farmers responded quickly to government subsidies promoting tea and camellia plantations, unplanned road construction was causing fragmentation, and official land-use map content differed from the authors' observations. Accordingly, the government should make integrated long-term plans for the development of ethnic-minority villages and engage in remote-sensor monitoring of local land-use change.
\end{abstract}

Keywords: land-use change; landscape patterns; landscape metrics; ethnic minorities

\section{Introduction}

Land is a spatial base for anthropogenic activities that provide natural resources such as food, plant matter, water and shelter to fulfil human needs [1]. Against this background, the Land-Use and Land-Cover Change (LUCC) scientific research program put forward under the International Geosphere-Biosphere Programme (IGBP) and the International Human Dimensions Programme on Global Environmental Change (IHDP) in 1993 prompted a rapid upward trend in research on land-use change [2,3]. While local intensive land usage has brought about an increase in food and fiber production while causing global environmental degradation in some regions [1,4,5], other areas have seen reduced land management or even abandonment, which jeopardize biodiversity and ecosystem services [5]. Research on land-use change in China has attracted much interest, while accelerated urbanization has brought about urban growth and cropland loss in China [6-8]. The processes, driving factors and ecological effects of rural land-use change in the mountainous areas of western China requires more research compared to the flourishing research in the metropolitan area in eastern and coastal China [9], since rural China is experiencing land-use problems, including the abandonment of farmland, non-agriculture, and non-grain preference [10,11].

Previous studies have concluded that land-use types and intensities are related to landscape structure, function and processes [12], and that landscape changes are most likely to be observed from changes in land use $[13,14]$. As such, it is important to integrate analysis 
of changes in land use and landscapes [15] in related research. While rapid development in such studies has been seen, most landscape-change analysis tended to focus on spatial patterns while neglecting landscape functions and processes, according to Bürgi et al.'s identification of challenges in the field in 2004. The authors concluded that further research on the driving forces behind landscape change may shed light on how to address related challenges [16]. The complexity of land-use systems calls for multidisciplinary analyses of the dynamic human-environment interactions associated with land-use change, but the lack of spatially explicit data makes it difficult to incorporate biophysical, socio-economic, and political factors [1,17]. Systematic analysis of local-scale land-use change studies can shed light on finding the general principles that can explain current land-use change and predict future land use systems [17].

Past research shows that traditional landscapes, managed by indigenous people based on traditional ecological knowledge (TEK), gained from long-term interaction with the surrounding environment, are resilient to disturbances, and that ecosystem services are maintained in such areas [18]. However, industrialization, urbanization and various significant changes in Chinese rural development policy have changed the lifestyles of indigenous people and rural landscapes [19]. The Dong people (one of 55 minorities in China) have long used TEK to manage their land, thereby supporting traditional characteristic landscapes. The Dong rice-fish-duck initiative in Guizhou is also designated as a Globally Important Agricultural Heritage System (GIAHS). Past research on natural resource utilization regimes in the Dong village of Gaoyou in southwestern China has shown intensive land-use regimes and interaction between different land-use elements in the traditional landscape, with results indicating that natural resource utilization has changed against a background of socio-economic development in modern China [20]. The rural revitalization goal announced as part of the CCP's 19th Congress in late 2017 aims to support commercial activity in rural areas, ecologically sound living environments, local interaction, effective governance and prosperity via promotion of development into rural China. However, the plan also raises certain challenges, including the need for market-based revitalization with a focus on rural land resources. While this approach may increase local property values, it may also deprive locals of their land [19]. Accordingly, there is an urgent need to clarify land-use changes in indigenous ethnic minority villages to determine the status of landscapes, thereby enabling plans for the preservation of traditional scenery and suggestions for the implementation of rural revitalization strategies.

With the prevalence of remote sensing technology and GIS, many researchers have used land satellite imagery and GIS to study changes in land-use/landscape patterns and related driving forces [3]. Recent years have also seen an increased interest in higherresolution data from unoccupied aircraft systems (UASs, or drones) for land-use/land-cover mapping [21] and change detection [22]. Recent papers revealed the implications of drones in precision agriculture and vegetation [23], urban environment and management [24], and disaster hazard and rescue [25]. Landscape metrics are often used to evaluate fragmentation. A variety of landscape metrics have also been developed and applied to quantify landscape composition and configuration [26-29].

The authors' previous research on Gaoyou involved a reconstruction of the present local landscape. Due to a lack of appropriate GIS data at the time, villagers were interviewed to enable the conclusion of results. In the study reported here, information from the previous research was used to interpret satellite imagery from 2009/2020 and drone imagery from 2019, and land classification maps were made.

The objectives of the research were to (1) determine spatio-temporal changes in land use; (2) clarify landscape pattern changes; and (3) identify major environmental factors contributing to changes in land use and landscape patterns. 


\section{Materials and Methods}

\subsection{Study Site}

The study was conducted in Gaoyou village of Sanjiang Dong Autonomous County, Liuzhou city, Guangxi Zhuang Autonomous Region, in southwest China $\left(25^{\circ} 59^{\prime} 02^{\prime \prime} \mathrm{N}\right.$, $109^{\circ} 52^{\prime} 35^{\prime \prime} \mathrm{E}$ ), which is on one of the headwaters of Lake Dongting and the Yangtze drainage basin. Although administratively Guangxi Region belongs to southern China, it is considered as a southwestern region in Chinese common sense due to its similarity with south-western China in topographical conditions, economic conditions, and dialect systems. Gaoyou is located on a mountain, with an average elevation of $500 \mathrm{~m}$, a subtropical climate, and hilly topographic conditions making the village suitable for forestry development, with major forestry species including fir trees (Cunninghamia lanceolata), pine trees (Pinus massoniana), bamboo and camellia (Camellia oleifera). Average temperatures are $26.2{ }^{\circ} \mathrm{C}$ in July and $10.7^{\circ} \mathrm{C}$ in January, and annual precipitation is $1300-1400 \mathrm{~mm}$. As shown in Figure 1, Gaoyou maintains a traditional Dong landscape with delicate wooden houses and diverse land usage, and is tentatively listed as a World Heritage site [30]. The study site is detailed in Table 1, and the location is shown in Figure 2.

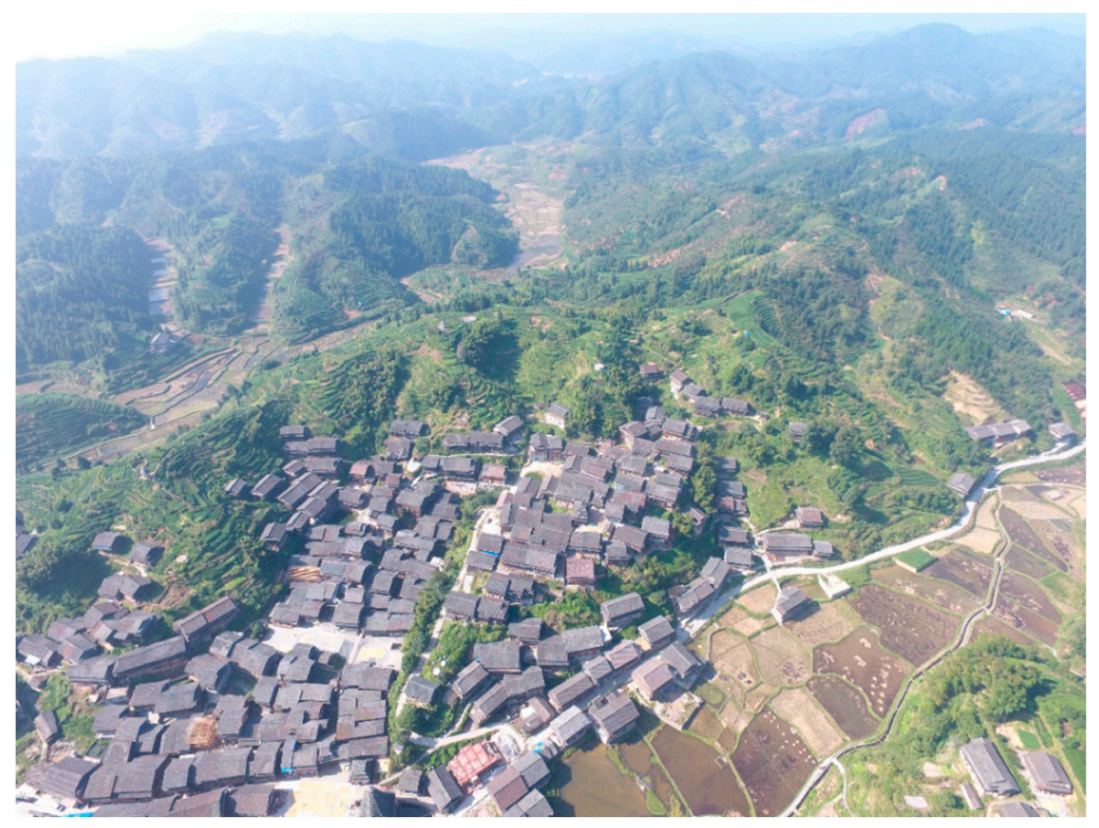

Figure 1. Aerial photo of Gaoyou village (photographed in 2017).

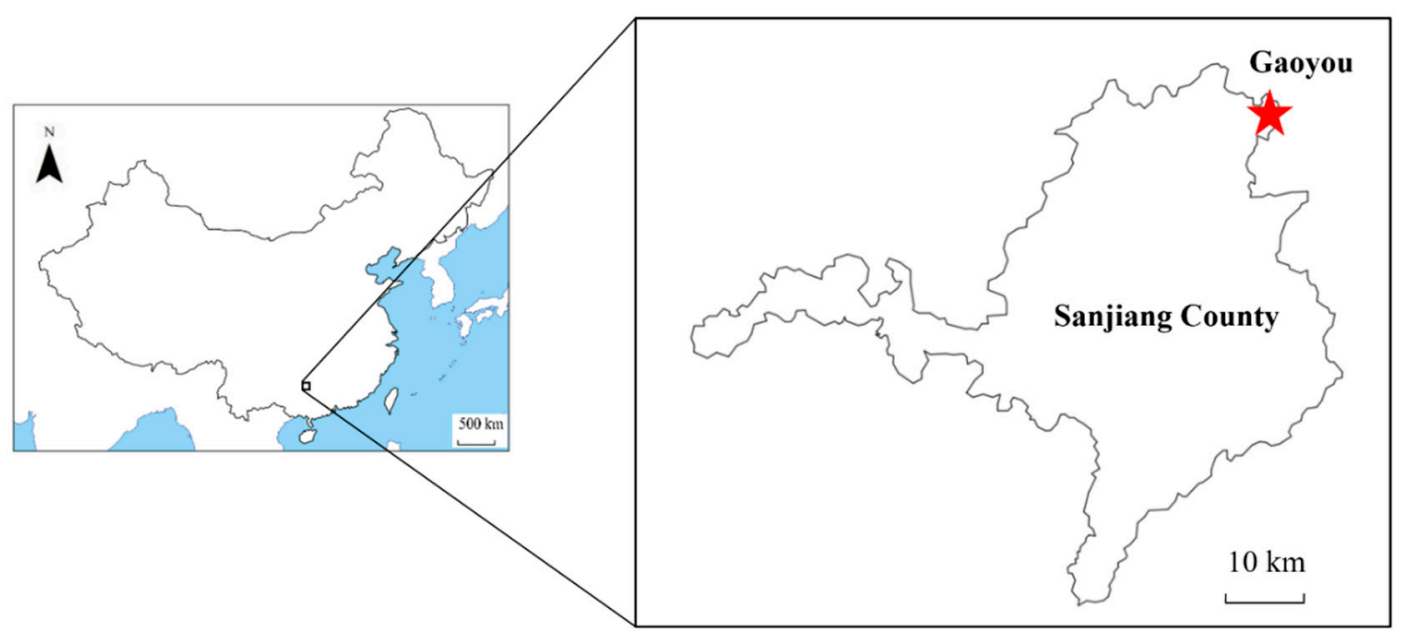

Figure 2. Gaoyou study area. 
Table 1. Official information about Gaoyou village.

\begin{tabular}{|c|c|c|c|c|c|c|c|c|c|}
\hline $\begin{array}{l}\text { Population } \\
\text { (Permanent } \\
\text { Residents }^{\mathbf{1}} \text { ) }\end{array}$ & Households & $\begin{array}{c}\text { Area } \\
\text { (ha) }\end{array}$ & $\begin{array}{c}\text { Farmland Area } \\
\text { (Paddy Fields) } \\
\text { (ha) }\end{array}$ & $\begin{array}{c}\text { Forest Area } \\
\text { (Fir/Camellia) } \\
\text { (ha) }\end{array}$ & $\begin{array}{c}\text { Tea } \\
\text { Plantations } \\
\text { (ha) }\end{array}$ & $\begin{array}{l}\text { Garden } \\
\text { Plots (ha) }\end{array}$ & $\begin{array}{c}\text { Built-Up } \\
\text { Land (ha) }\end{array}$ & $\begin{array}{c}\text { Other } \\
\text { Area (ha) }\end{array}$ & $\begin{array}{c}\text { Average } \\
\text { Elevation } \\
\text { (m) }\end{array}$ \\
\hline $1960(1230)$ & 496 & 530.5 & $89.5(85.2)$ & $330.9(153.3 / 86.7)$ & 39.5 & 43 & 15.2 & 12.4 & 500 \\
\hline
\end{tabular}

${ }^{1}$ Permanent residents are farmers staying in the village for more than six months a year. Data source: Gaoyou Government, recorded from official planning for 2020-2035 as of 2020.

\subsection{Methods}

\subsubsection{Data Collection and Processing}

Land-use changes in Gaoyou were determined by comparing land use/land cover classification maps for 2009, 2019 and 2020. Those for 2009 and 2020 were derived from GeoEye-1 satellite imagery (spatial resolution: $46 \mathrm{~cm}$ ) acquired on 9 February 2009 and 14 November 2020. The one for 2019 was derived from Phantom 4 Pro drone imagery from two flight missions captured at the flight height of $270 \mathrm{~m}$ on 11 May 2019, after we finished our previous baseline research in this village using the method of interview in 2018 [20]. The time was chosen during the rice transplanting season when paddy fields are filled with water and can easily be identified from the drone imagery. During the field surveys in this village conducted between 2017 and 2020, an increase in tea plantation due to the continuous governmental promotion from 1990s was observed, and a new land-use change from other land-use types into camellia plantations was observed after the governmental promotion of camellia planation by subsidies in 2018. Therefore, the land use composition of this village before and after 2019 and the time that we took the drone imagery as baseline information was considered important. The satellite imageries of 2009 and 2020 were selected because they are the only available satellite data suitable for visual interpretation. The drone imagery was processed in Agisoft Metashape Professional to produce an orthophoto mosaic of Gaoyou with a resolution of $11 \mathrm{~cm}$ (Figure 3). Satellite data were georeferenced to drone data via 150 ground control points in ArcMap 10.7. All imagery was later processed in ArcGIS 10.7 to create thematic land-use categorization maps, which were visually interpreted by the same researcher to minimize potential inconsistencies. With reference to the authors' previous research on landscape mapping in Gaoyou [20], the land-use types were mixed forest, fir plantation, camellia plantation, tea plantation, paddy field, dry field, barren land, residential area, and road (Table 2). The land uses also considered that since the resolutions of the imagery data were different, each land use type could be clearly identified from each of the images, and each polygon was relatively homogenous and differed from the surroundings. The only difficulty was in distinguishing between paddy field and dry field in the satellite imageries with resolution of $46 \mathrm{~cm}$. Since the paddy field can be identified from the drone imagery with resolution of $11 \mathrm{~cm}$, and due to China's "Red Line" policy for arable land under which farmers may not make changes to paddy fields, and it is very unlikely that farmers reclaim new paddy field in the recent years, we assumed that the paddy field would remain unchanged and interpreted the farmland identified in the satellite imagery as paddy field wherever the same area was identified as paddy field in the drone imagery. As the official administrative boundary of the village was unclear in 11 May 2019, the study area in relation to drone imagery was determined from group discussions in which villagers were asked where they acquired natural resources. The village border was then determined in consideration of geographical boundaries such as mountain ridges and landmarks such as large pine trees. ASTER DEM information (spatial resolution: $30 \mathrm{~m}$ ) produced by Japan's Ministry of Economy, Trade and Industry and NASA data were used to derive environmental variables including altitude, slope and aspect in ArcGIS 10.7. 


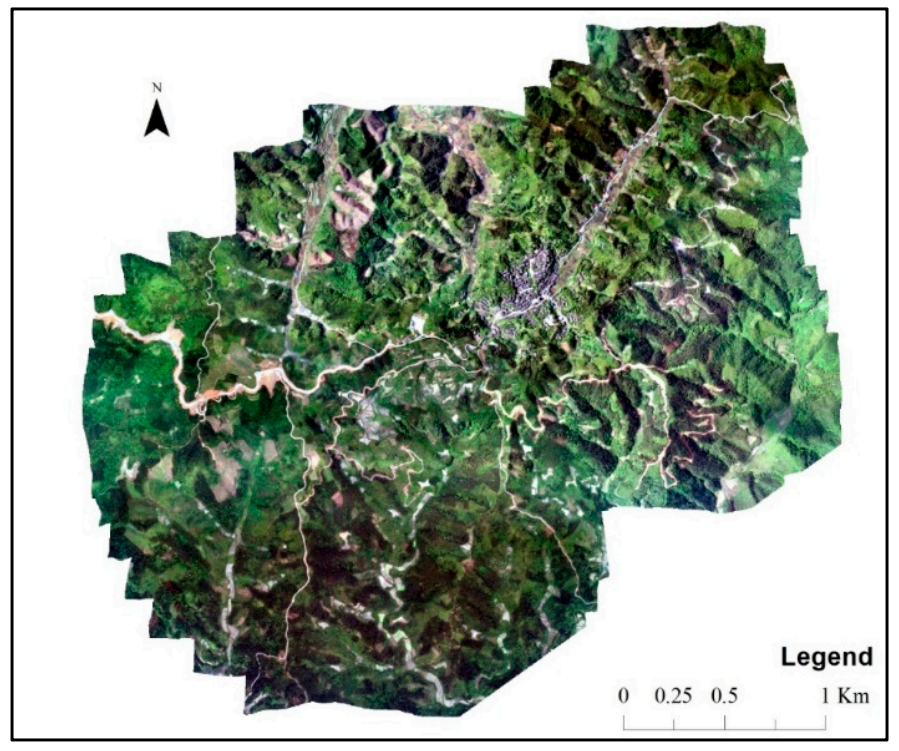

Figure 3. Orthophoto mosaic (11 cm pixel size) of Gaoyou in 2019.

Table 2. Land use types.

\begin{tabular}{|c|c|}
\hline Type & Description \\
\hline Mixed forest & $\begin{array}{c}\text { Including planted forests other than fir and camellia plantations and } \\
\text { natural forests }\end{array}$ \\
\hline Fir plantation & Plantation of fir trees \\
\hline Camellia plantation & Plantation of camellia trees \\
\hline Tea plantation & Plantation of tea bushes \\
\hline Paddy field & Irrigated paddy field for rice and glutinous rice cultivation \\
\hline Dry field & $\begin{array}{l}\text { Irrigated paddy field for crops other than rice, rainfed paddy field } \\
\text { (including dry rice cultivation), irrigated cropland (for example peanut } \\
\text { field), rainfed cropland (for example sweet potato field), and vegetable } \\
\text { field (for example leek field). }\end{array}$ \\
\hline Barren land & $\begin{array}{c}\text { Cleared land with no vegetation or structures, usually indicating that the } \\
\text { old land use is cleared to change into another land use or will be left } \\
\text { unmanaged }\end{array}$ \\
\hline Settlement & Houses and nearby open areas, pathways and vegetable gardens \\
\hline Road & Road for automobiles \\
\hline
\end{tabular}

Interviews with villagers and local administrators were conducted during land-use mapping and analysis of land-use changes in Gaoyou.

\subsubsection{Analysis of Land Use and Landscape Pattern Changes}

The land-use classification maps for 2009-2019-2020 were imported into the Fragstats program for extraction of more information on land-use/landscape pattern changes from various landscape metrics [26,29]. Patches, which are the fundamentals for calculating landscape metrics, are represented with polygons of identified land-use types in each year [26]. Landscape metric computations were conducted at the class-level, in which all patches belonging to the same land-use type were aggregated, and at the landscape-level, where all patches in the landscape were aggregated.

The class-level landscape metrics describing changes in land-use type changes were: total (class) area (CA) and percentage of landscape (PLAND) to highlight land-use changes; number of patches (NP) and splitting index (SPLIT) to describe fragmentation levels; largest patch index (LPI) and perimeter area fractal dimension (PAFRAC) to describe changes in patch shapes for each land-use type; and the aggregation index (AI) to determine increased aggregation of land use. 
The metrics for the landscape level were the number of patches (NP) and the splitting index (SPLIT) used to determine the extent of landscape subdivision or fragmentation, the landscape shape index (LSI) describing changes in patch shape, the contagion index (CONTAG) and aggregation index (AI) used to determine landscape aggregation extent, and Shannon's diversity index (SHDI)/Shannon's evenness index (SHEI) to describe changes in landscape diversity (Tables 3 and 4 ).

Table 3. Landscape metrics at class level for land-use change analysis.

\begin{tabular}{ccc}
\hline & Abbreviation & Range \\
\hline Total (class) area & CA & CA $>0$, without limit \\
Percentage of landscape & PLAND & $0<$ PLAND $\leq 100$ \\
Number of patches & NP & NP $>0$, without limit \\
Largest patch index & LPI & $0<$ LPI $\leq 100$ \\
Perimeter area fractal & PAFRAC & $1 \leq$ PAFRAC $\leq 2$ \\
dimension & & $1 \leq$ SPLIT $\leq$ number of cells in the landscape \\
Splitting index & SPLIT & area squared \\
Aggregation index & AI & $0 \leq$ AI $\leq 100$ \\
\hline
\end{tabular}

Table 4. Landscape metrics at landscape level for pattern change analysis.

\begin{tabular}{ccc}
\hline & Abbreviation & Range \\
\hline Number of patches & NP & NP $>0$, without limit \\
Landscape shape index & LSI & LSI $\geq 1$, without limit \\
Contagion index & CONTAG & $0 \leq$ CONTAG $\leq 100$ \\
Aggregation index & AI & $0 \leq$ AI $\leq 100$ \\
Splitting index & SPLIT & $1 \leq$ SPLIT $\leq$ number of cells in the \\
Shannon's diversity index & SHDI & landscape squared \\
Shannon's evenness index & SHEI & SHDI $\geq 0$, without limit \\
\hline
\end{tabular}

As was mentioned before, minimal changes in paddy field characteristics were assumed due to the difficulty of distinguishing between paddy and dry fields from satellite images, and due to China's "Red Line" policy for arable land under which farmers may not make changes to paddy fields. As minimal change was identified in satellite imagery, only CA and PLAND values were calculated for paddy fields. CA and PLAND road areas were calculated because roads comprise a significant part of the village's land. The total road length was determined to represent road change in each year instead of other landscape metrics at class level. Details of the calculation and associated ecological meanings of these landscape metrics can be found in the related studies [26,28,31].

\subsubsection{Analysis of Land-Use Change Trajectories and Environmental Drivers of Change}

Multivariate analysis was applied to demonstrate the relationship between land-use change trajectories and environmental drivers. The land-use classification maps were processed in ArcMap 10.7 to develop a spatial-temporal database with layers showing land-use types in 2009, 2019 and 2020, and of environmental variables. A $10 \mathrm{~m}$ by $10 \mathrm{~m}$ grid was created for the three land-use maps, and land-use change trajectories [32] and environmental variables were recorded in each sample. This produced 65,210 samples evenly distributed across the landscape. A letter was assigned to each of the nine land-use types (tea plantation (T), camellia plantation (C), dry field (D), barren land (B), fir plantation $(F)$, road (R), mixed forest $(\mathrm{M})$, paddy field $(\mathrm{P})$ and settlement $(\mathrm{S})$ ) and the land-use type that occupies the maximum area of the grid was recorded in each sample in 2009, 2019 and 2020. Land-use change trajectories, defined as the land use change in each temporal sequence (2009-2019 and 2019-2020), were built by comparing the recorded land use type in each sample in the corresponding year (e.g., a land-use change trajectory may be DT in 
2009-2019 (D = dry field, T = tea plantation) and DT in 2009-2019 represents the sample land-use type changed from dry field to tea plantation; and DD in 2009-2019 represents stable dry fields in this time period) [32-34].

To introduce the trajectories into multivariate analysis, the qualitative land-use type data were binary-coded and converted into presence-absence data [34]. These were then divided into two sets of 81 variables, each representing one of the nine land-use types at two time points in individual time intervals (2009 and 2019, and 2019 and 2020). A total of 65 land-use change trajectories were observed between 2009 and 2019 and 53 between 2019 and 2020, with variables comprising more than 0.1 percent of land-use change chosen for multivariate analysis. These included 38 types for 2009 and 2019 and 22 for 2019 and 2020.

Table 5 summarizes the environmental variables, with altitude directly derived from ASTER DEM and aspect/slope derived from DEM using the spatial analysis function in ArcGIS 10.7. Aspect data were classified as 1 (flat terrain), 2 (north, $0-22.5^{\circ}$ and

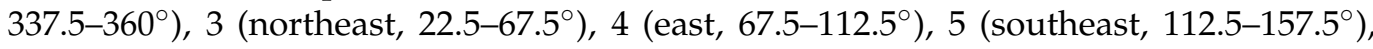

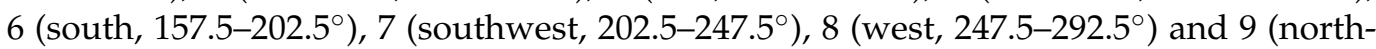
west, $\left.292.5-337.5^{\circ}\right)[28,33]$. The environmental variables of distance to rivers, distance to settlements and distance to roads were derived from land-use map data for 2009 because more roads were constructed in the following years, and those in 2009 were the main ones. The location of the Gulou Drum Tower used in calculating distance to settlements and the location of rivers did not change during 2009-2020. Distance to settlements was based on the Euclidean distance from the central point of the sample grid to Gulou Drum Tower, which is considered the central point of the village. Distance to rivers was based on the Euclidean distance from the central point of the sample grid to the river.

Table 5. Statistical analysis of environmental diversity in Gaoyou.

\begin{tabular}{ccccc}
\hline \multicolumn{2}{c}{ Environmental Variable } & Range & Median & $\begin{array}{c}\text { Standard } \\
\text { Deviation }\end{array}$ \\
\hline Natural attributes & Altitude $(\mathrm{m})$ & $325-620$ & 504 & 64.88 \\
& Slope & $0.3-44.5$ & 15.1 & 7.50 \\
& Aspect & $1-9$ & 5 & 1.96 \\
& Distance to rivers $(\mathrm{m})$ & $0-1500$ & 300 & 264.30 \\
\hline Anthropogenic attributes & Distance to settlements (m) & $0-2800$ & 1050 & 612.24 \\
& Distance to roads $(\mathrm{m})$ & $0-1103$ & 160 & 217.95 \\
\hline
\end{tabular}

All data processing for multivariate analysis was conducted in RStudio, with direct gradient analysis used to clarify relationships between land-use change and environmental variables. Initial testing of environmental gradient lengths using detrended correspondence analysis (DCA) indicated axis lengths of $<3$ SD in all cases, indicating the appropriateness of redundancy analysis (RDA) for this dataset [35].

RStudio was used for RDA analysis of the relationship between land-use change, trajectory type and environment variables for 2009-2019 and 2019-2020.

\section{Results}

\subsection{Land-Use Maps for 2009, 2019 and 2020}

Figure 4 shows results of land-use maps for 2009, 2019 and 2020 from visual interpretation of satellite and drone imageries. Those for 2009-2019 and 2019-2020 were used to make maps of new land use for each time period, as shown in Figure 5. A comparison shows that $29.7 \%$ of all land-use types changed during 2009-2019 (around 3\% for each year) and $9.1 \%$ during 2019-2020. 

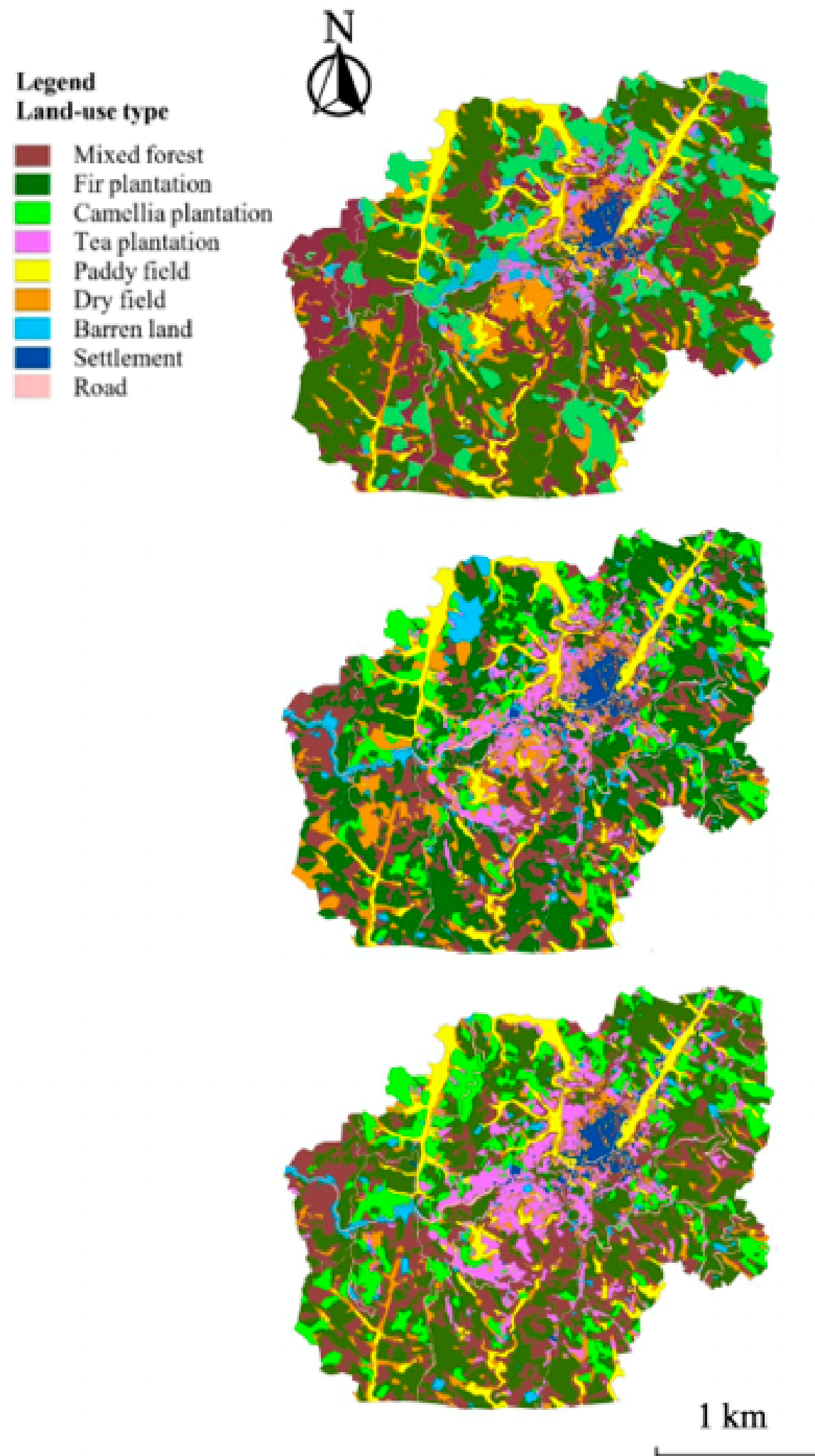

Figure 4. Land use maps for 2009, 2019 and 2020. 


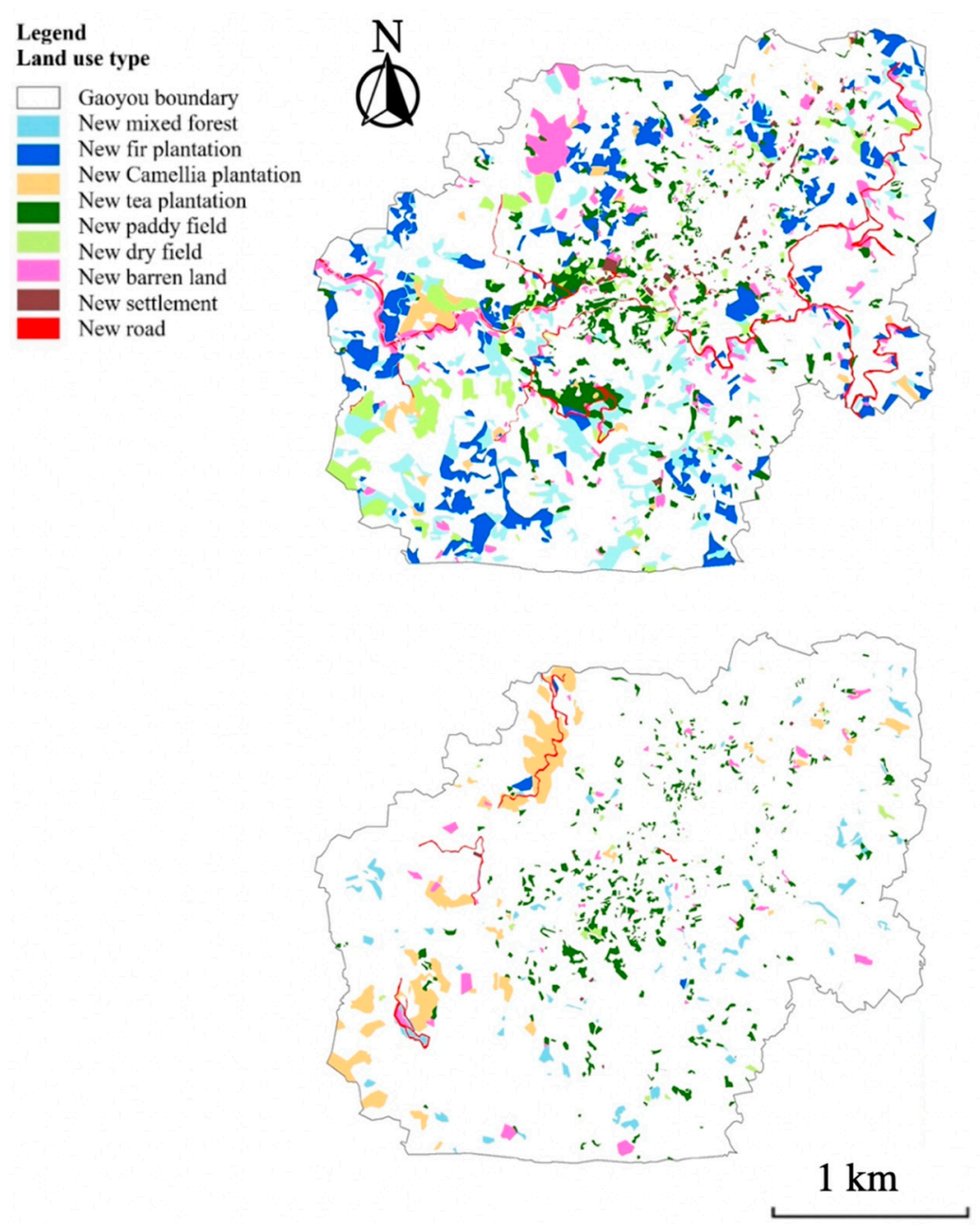

Figure 5. Maps of new changes in land use for 2019 and 2020.

Changes in different land-use types for 2009-2019 and 2019-2020 are shown in Figure 6. During 2009-2019,70.3\% of types in the samples remained unchanged, although part of the mixed forest areas changed into other types. As small fir plantations are difficult to identify from satellite imagery and are often mixed with other vegetation types, fir saplings are sometimes categorized as mixed plantation areas. Between 2009 and 2019 there was a significant change of mixed forest to fir forest, indicating the planting of fir saplings or their growth. There is also a change from fir plantation to mixed plantation, indicating that firs were not replanted after timber harvesting, or that fir saplings were too small to be identified. The land-use type of fir plantation is mostly changed to the land-use types of barren land, dry field or road, with changes to barren land suggesting use for other purposes. Reduced camellia plantation use is seen during 2009-2019, with many areas changing to fir plantations, while 2019-2020 exhibits an increase in camellia plantation use from dry fields and barren land. A change in dry fields (mainly used for growing sweet potatoes and leek) is observed throughout the study period, with a particular change to camellia plantations during 2019-2020. Changes of barren land (indicating land-use change) into tea plantations during 2009-2019 are associated with land clearance before 2009. Between 2019 and 2020, more barren land changed into camellia plantations than into tea plantations. Villagers report that land was cleared for tea plantation before 2019, but a decision was made to create camellia plantations instead during that year. Barren land was also created along the new road in association with road construction during 2009 and 2019, and was thereafter left unmanaged to create mixed forest naturally in 2020. A 
continuous increase in use for tea plantations is observed. The new road areas were mostly fir plantation, creating a landscape of roads cutting through local forests.

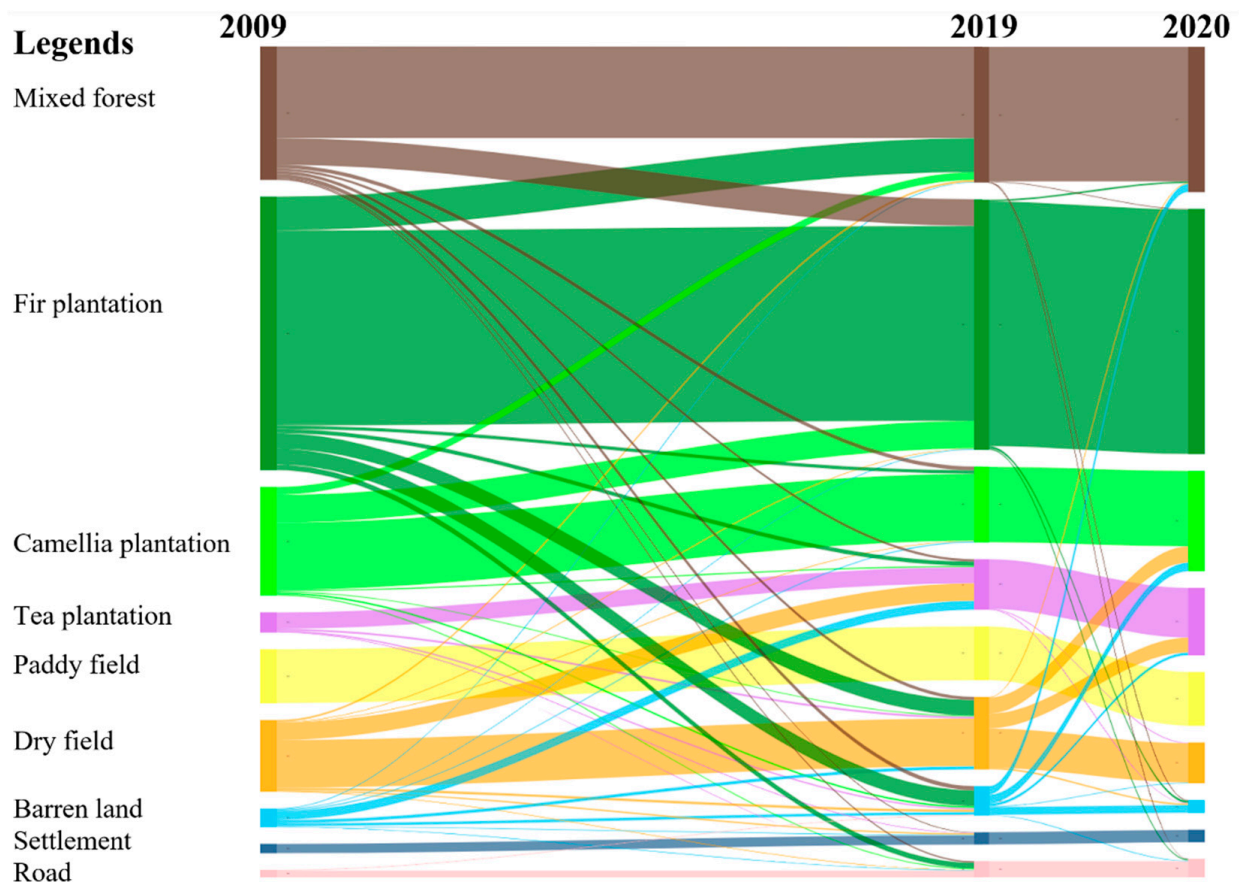

Figure 6. Land-use compositions for 2009, 2019 and 2020, and related inter-year changes indicated by flows between land-use types in each year.

\subsection{Changes in Land Use and Landscape Patterns}

Due to a lack of data showing the change of physical landscape in the research area in the study period, only the change of landscape quality in terms of the structure of land cover was studied. The land-use maps for 2009, 2019 and 2020 were imported into Fragstats for calculation of selected landscape metrics.

\subsubsection{Changes in Landscape Metrics at Class Level}

Changes in each land-use type were studied using landscape metrics at class level. The CA and PLAND landscape metrics at class level (representing the area of each land-use type) are shown in Table 6, while changes in NP, LPI, PAFRAC, SPLIT, AI and road length are shown in Figure 7. Table 7 shows the rate of annual change in areas of each land-use type calculated from Table 6, indicating acceleration for both increases and decreases.

Table 6. Total area coverage between 2009 and 2020 for the classified land-use types. CA: total (class) area; PLAND: percentage of landscape.

\begin{tabular}{ccccccc}
\hline & \multicolumn{2}{c}{$\mathbf{2 0 0 9}$} & \multicolumn{2}{c}{$\mathbf{2 0 1 9}$} & \multicolumn{2}{c}{$\mathbf{2 0 2 0}$} \\
\cline { 2 - 7 } Land-Use Type & CA (ha) & PLAND (\%) & $\begin{array}{c}\text { CA } \\
\text { (ha) }\end{array}$ & PLAND (\%) & CA (ha) & PLAND (\%) \\
\hline Mixed forest & 125 & 19.13 & 127 & 19.53 & 136 & 20.81 \\
Fir plantation & 256 & 39.22 & 234 & 35.89 & 228 & 35.05 \\
Camellia plantation & 102 & 15.59 & 71 & 10.90 & 94 & 14.41 \\
Tea plantation & 19 & 2.91 & 47 & 7.25 & 63 & 9.68 \\
Paddy field & 51 & 7.76 & 50 & 7.71 & 50 & 7.69 \\
Dry field & 67 & 10.29 & 68 & 10.41 & 38 & 5.87 \\
Barren land & 17 & 2.68 & 27 & 4.22 & 13 & 2.04 \\
Settlement & 9 & 1.34 & 11 & 1.76 & 12 & 1.80 \\
Road & 7 & 1.09 & 15 & 2.32 & 17 & 2.64 \\
\hline Total & 652 & 100 & 652 & 100 & 652 & 100 \\
\hline
\end{tabular}




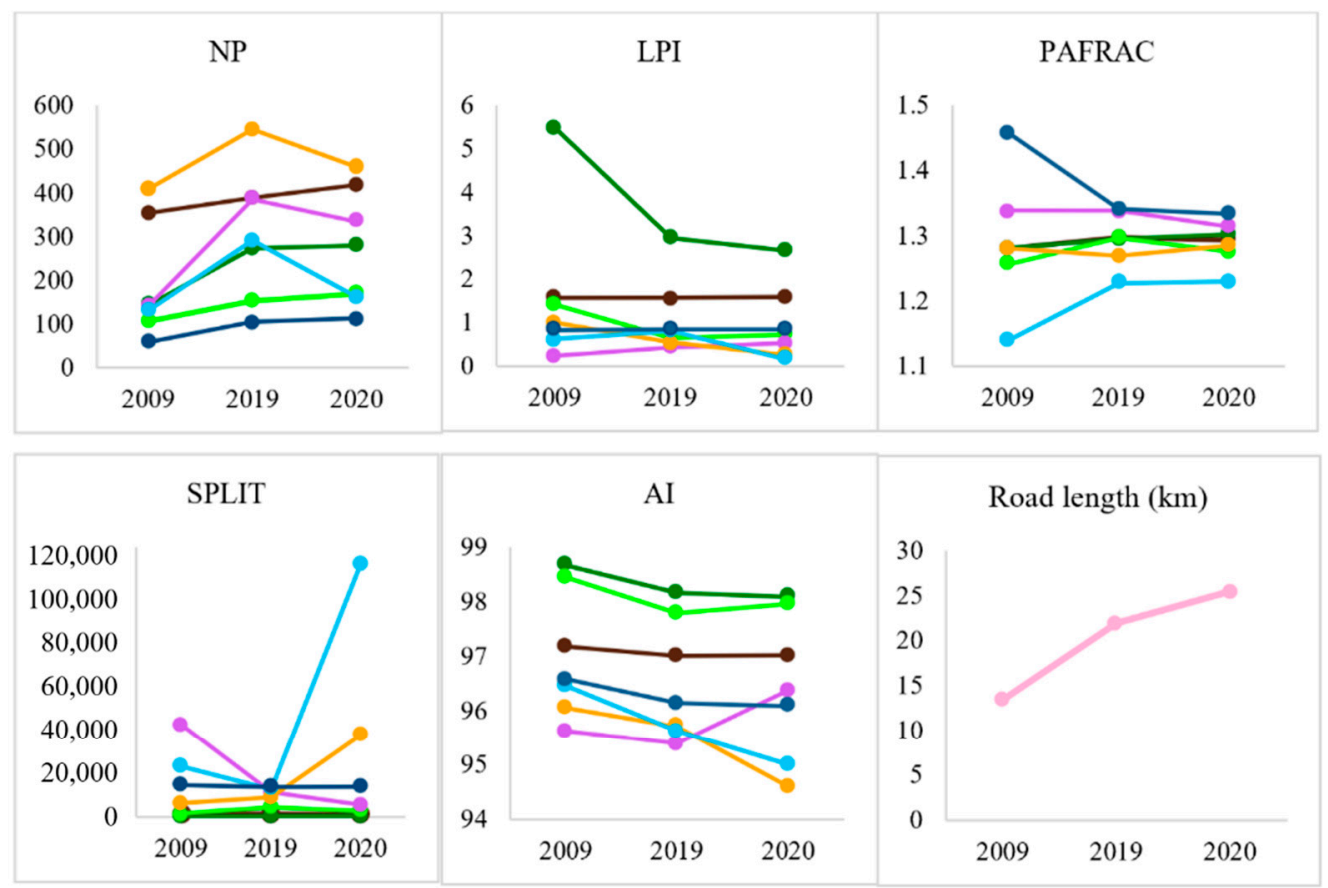

\section{Legend}

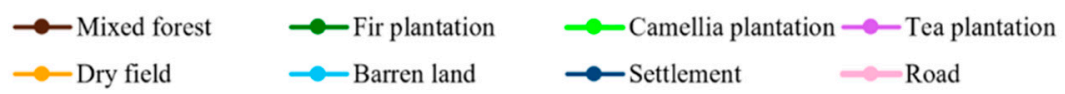

Figure 7. Changes in landscape metrics at class level. NP: number of patches; LPI: largest patch index; PAFRAC: perimeter area fractal dimension; SPLIT: splitting index; AI: aggregation index.

Table 7. Percentage change, net change and rate of change between 2009, 2019 and 2020 for the classified land-use categories.

\begin{tabular}{|c|c|c|c|c|c|c|c|c|c|}
\hline \multirow{2}{*}{ Land-Use Type } & \multicolumn{3}{|c|}{ Change (\%) } & \multicolumn{3}{|c|}{ Net Change (ha) } & \multicolumn{3}{|c|}{ Rate of Change (ha/Year) } \\
\hline & 2009-2019 & 2019-2020 & 2009-2020 & 2009-2019 & 2019-2020 & 2009-2020 & 2009-2019 & 2019-2020 & 2009-2020 \\
\hline Mixed forest & 0.40 & 1.28 & 1.68 & 2 & 9 & 11 & 0.2 & 9 & 1 \\
\hline Fir plantation & -3.33 & -0.84 & -4.17 & -22 & -6 & -28 & -2.2 & -6 & -2.5 \\
\hline $\begin{array}{l}\text { Camellia } \\
\text { plantation }\end{array}$ & -4.69 & 3.51 & -1.18 & -31 & 23 & -8 & -3.1 & 23 & -0.7 \\
\hline Tea plantation & 4.34 & 2.43 & 6.77 & 28 & 16 & 44 & 2.8 & 16 & 4 \\
\hline Paddy field & -0.05 & -0.02 & -0.07 & -1 & 0 & -1 & -0.1 & 0 & -0.1 \\
\hline Dry field & 0.12 & -4.54 & -4.42 & 1 & -30 & -29 & 0.1 & -30 & -2.6 \\
\hline Barren land & 1.54 & -2.18 & -0.64 & 10 & -14 & -4 & 1 & -14 & -0.4 \\
\hline Settlement & 0.42 & 0.04 & 0.46 & 2 & 1 & 3 & 0.2 & 1 & 0.3 \\
\hline Road & 1.23 & 0.32 & 1.55 & 8 & 2 & 10 & 0.8 & 2 & 0.9 \\
\hline
\end{tabular}

The increasing NP and the decreasing AI indicate mixed forest fragmentation. For fir plantations, the increased NP and PAFRAC and the decreased LPI and AI indicate lower aggregation, with large areas divided into smaller patches. Dry fields are also less aggregated, as indicated by the increased SPLIT and decreased AI. Camellia plantations exhibit different trends of landscape metric change for the time sequence 2009-2019-2020, with a large portion of camellia plantations in 2019, an increased SPLIT and a decreased AI in 2009-2019, and a decreased SPLIT and an increased AI in 2019-2020 showing fragmentation of old camellia plantations and aggregation of new camellia plantations. Tea plantations exhibit increased size, with simpler and more aggregated areas. Residential zones show increased and less aggregated areas. Roads (Table 8) show increased area, length and width calculated by road length divided by road area in each year. 
Table 8. Road changes.

\begin{tabular}{cccc}
\hline & Length $\mathbf{( k m )}$ & Area (ha) & Width $(\mathbf{m})$ \\
\hline 2009 & 13.4 & 7 & 5.2 \\
2019 & 22.0 & 15 & 6.8 \\
2020 & 25.5 & 17 & 6.7 \\
\hline
\end{tabular}

3.2.2. Changes in Landscape Metrics at Landscape Level

Figure 8 shows changes in landscape patterns from metrics at landscape level.

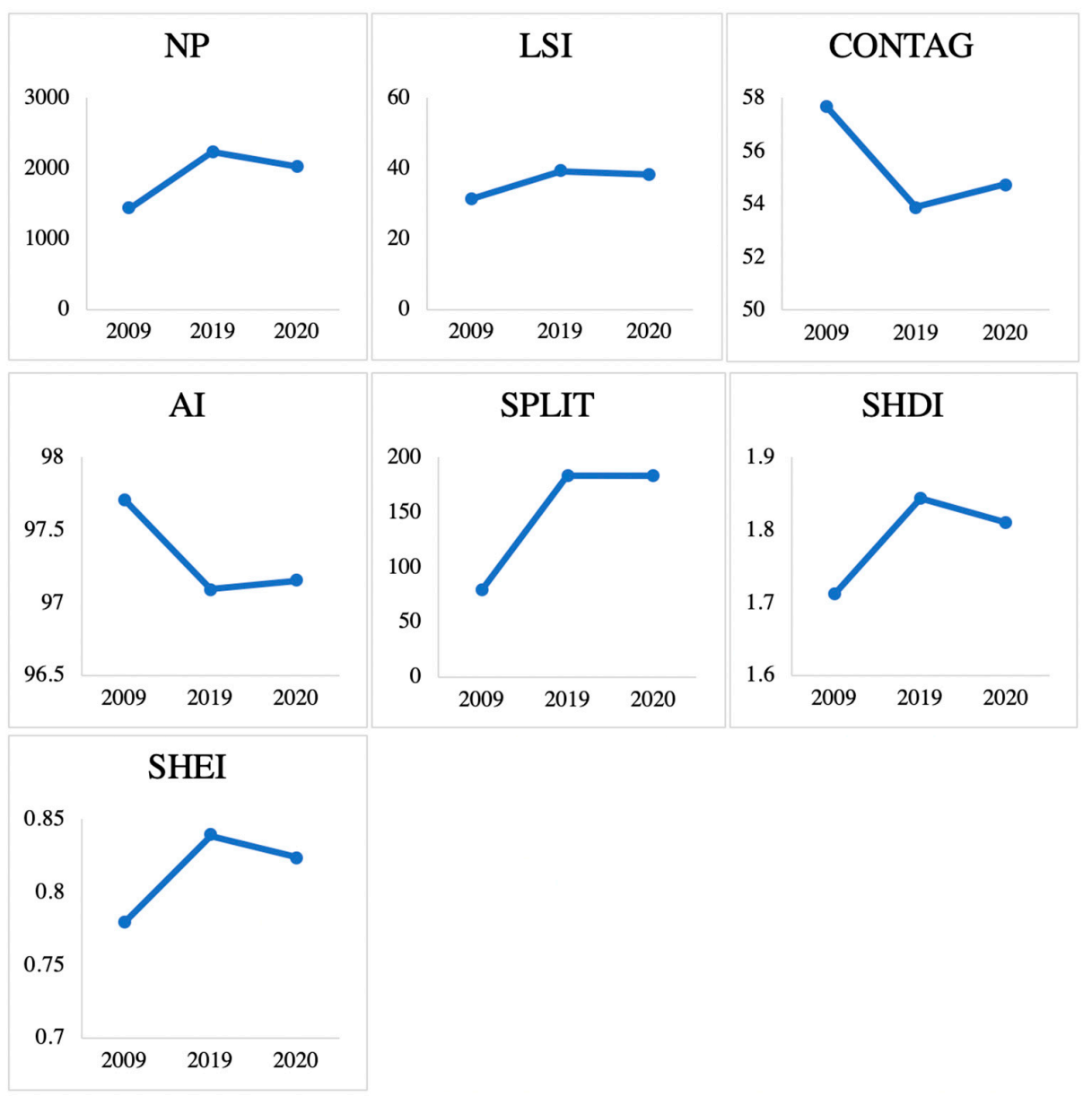

Figure 8. Changes in landscape metrics at landscape level. NP: number of patches; LSI: landscape shape index; CONTAG: contagion index; AI: aggregation index; SPLIT: splitting index; SHDI: Shannon's diversity index; SHEI: Shannon evenness index.

In summary, before 1990 when tea plantations were first introduced in Gaoyou, local land use was mainly comprised of traditional land-uses of the Dong people and the landuses introduced during the People's Commune Period [20]. Increased plantation of tea during 2009-2019 resulted in greater landscape diversity and caused fragmentation and disaggregation, leading to landscape irregularity. However, new tea/camellia plantation from 2019 onward combined these aggregated and detached patches to create larger areas, thereby simplifying the landscape and reducing diversity.

\subsubsection{Relationship between Land Cover Change and Environmental Variables}

A total of 65 land-use change trajectories for 2009-2019 and 53 for 2019-2020 were identified. Less significant trajectories comprising less than 0.1 percent of the landscape were omitted in the RDA analysis conducted to establish the relationship between land-use 
change and environmental variables. These included 38 land-use change trajectories for 2009-2019 and 22 for 2019 and 2020.

In the RDA analysis results shown in Figures 9 and 10, the first 2 RDA axes for 2009-2019 account for $72.64 \%$ of the total variation, and those for the second time period account for $85.4 \%$. These figures highlight the relationship between land-use change and environmental variables in Gaoyou.

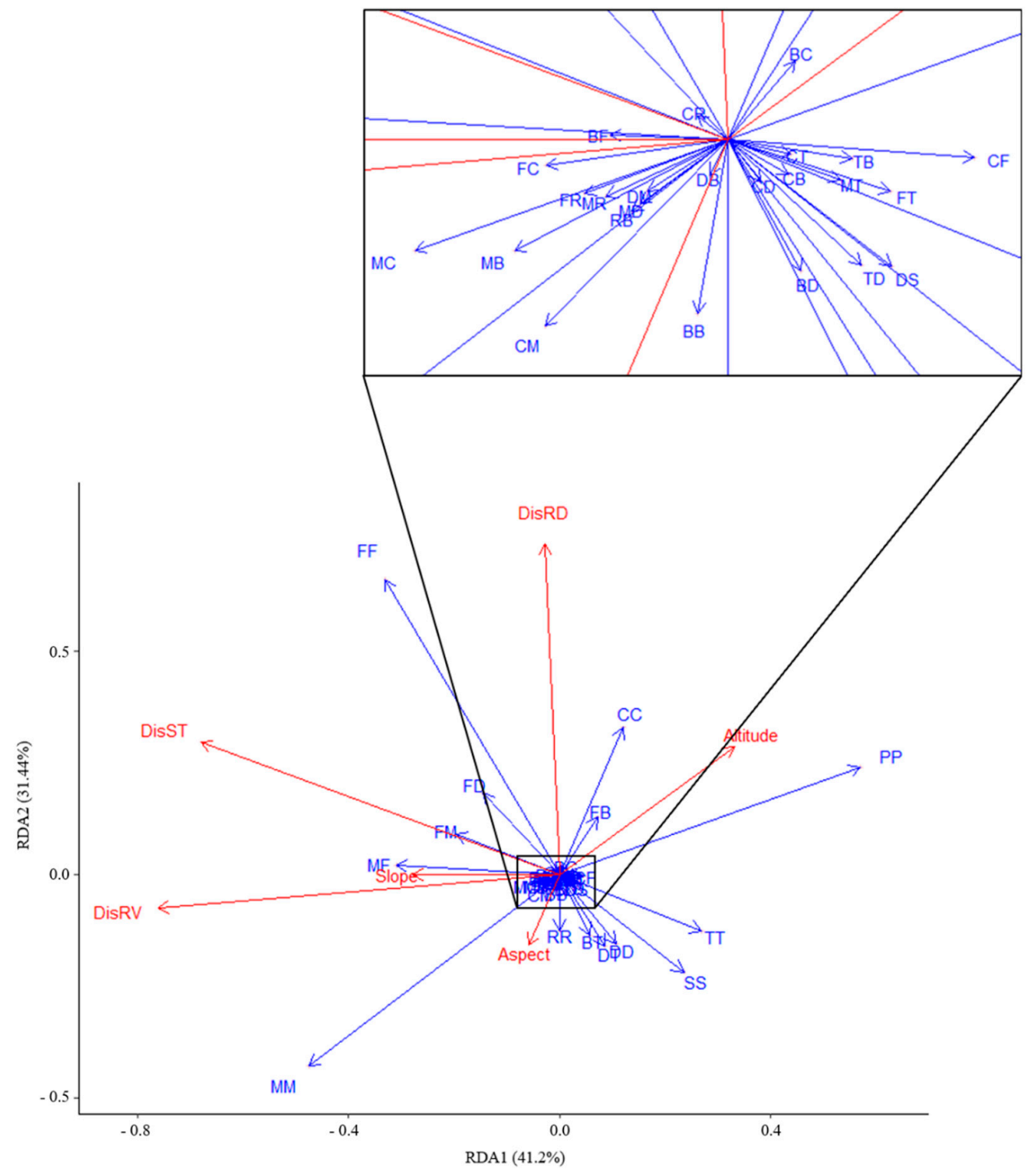

Figure 9. RDA ordination of land-use change trajectories (blue arrows) in relation to environmental variables (red arrows) for 2009-2019. DisRV: distance to rivers; DisRD: distance to roads; DisST: distance to settlements. Arrows represent relative values of environmental variables and land-use change trajectories. Correlations between environmental variables and land-use change trajectories are indicated by the cosine of angles between the corresponding arrows, with $<90^{\circ}$ indicating a positive correlation and $>90^{\circ}$ a negative correlation. With projection of arrows for land-use change trajectories into arrows for corresponding environmental variables, the distance from the origin to the projection point indicates the relative value of the environmental variable where land-use change is most likely to occur. 


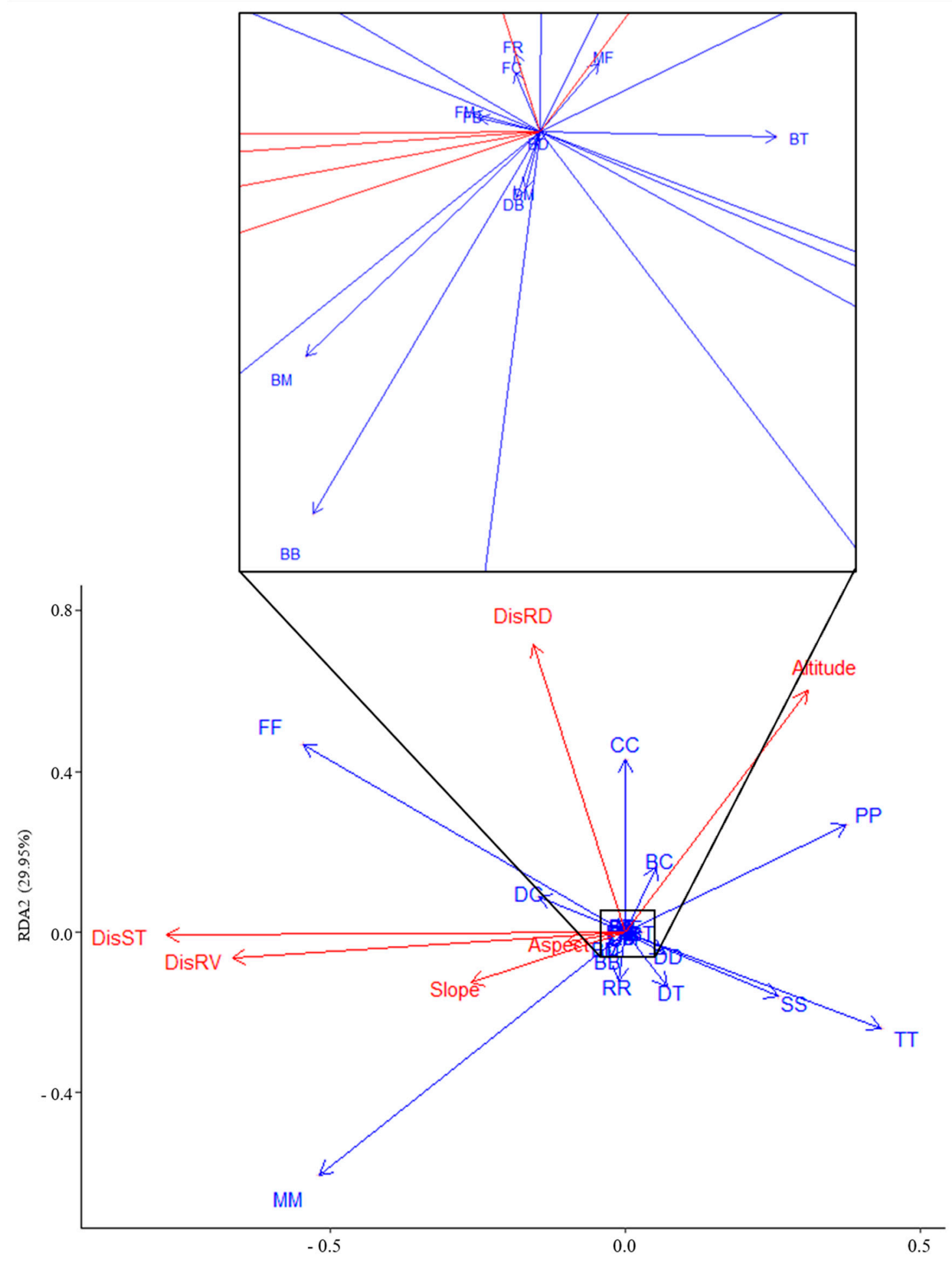

Figure 10. RDA ordination of land-use change trajectories (blue arrows) in relation to environmental variables (red arrows) for 2019-2020. DisRV: distance to rivers; DisRD: distance to roads. DisST: Distance to settlement. Arrows represent relative values of environmental variables and land-use change trajectories. Correlations between environmental variables and land-use change trajectories are indicated by the cosine of angles between the corresponding arrows; with $<90^{\circ}$ indicating a positive correlation and $>90^{\circ}$ a negative correlation. With projection of arrows for land-use change trajectories into arrows for corresponding environmental variables, the distance from the origin to the projection point indicates the relative value of the environmental variable where land-use change is most likely to occur. 
In both time periods, it is more likely that unchanged areas of mixed forests, fir plantations and camellia plantations are distant from village and road zones and on steep slopes; stable tea plantation and dry field areas are close to village and road zones; paddy field and settlement areas are on flat land close to river zones; and barren land is at low altitudes close to road zones.

In both time periods, it is more likely that land distant from village zones and on steep slopes was changed to mixed forest; forests distant from village or road zones and at high altitude or on steep slopes changed to fir plantations; forests and farmland distant from village and road zones and on steep slopes or at high altitude changed into camellia plantations; land very close to village and road zones and with some sloping changed into tea plantations; and land close to village and road zones changed into dry fields. New roads are built on relatively steep slopes, and land near the new road zones was changed into barren land.

\section{Discussion}

\subsection{Direction of Land-Use Change in Gaoyou}

The research results show that nearly $30 \%$ of local land underwent change between 2009 and 2019 (annual rate of change: 3\%) and 9\% between 2019 and 2020, and the pace of change is accelerating. Although some changes (such as those between fir plantations and mixed forests) may be attributable to natural succession and research deficiencies, most were related to human activity.

The results, including maps showing the location of land-use types from Figure 4 , the location of new land-use from Figure 5, mean values of environmental variables for each land-use type, and location of land-use change trajectory in relation to environmental variables from Figures 9 and 10, were summarized and combined with those of the authors' previous research [20] and interviews with villagers and local administrators to create the transect model in Figure 11 showing the direction of land-use changes. As tea plantations were first established in Gaoyou in 1990, land use before this time was used as a reference. Due to a lack of satellite imagery that can be used for analyzing the land use composition of Gaoyou from before 2009, three groups of villagers were organized to discuss and highlight major land-use changes occurring between 1990 and 2009. Barren land is not included in the model, as it indicates land-use transition.

Before the establishment of tea plantations in the 1990s, there was no traffic access. The land-use types in Gaoyou were mainly traditional land-use of the Dong people and the land-use types that were brought into the village by the government during the People's Commune Period [20]. Paddy fields running along the riverside were flanked by residential areas, and dry fields behind the village were situated with fir and camellia plantations. There was also forest and farmland at low altitudes distant from the village. In 2009, a road was constructed on the old path in the area. Camellia is a traditional Dong plantation that was previously used for plant oil production, but today it is used for other purposes because oil is now purchased from the market. Tea plantation is prevalently promoted, and some camellia plantations and dry fields have been converted for this purpose. Developments in the energy sector have also reduced demand for firewood, meaning that mixed forest areas have recovered. Depopulation has left dry fields unmanaged, creating barren land. In 2019, a significant increase in tea plantation areas was observed, with some farmers switching from camellia plantations and dry field areas. More roads have also been constructed in forest areas. In 2020, when the plantation of a new species of camellia was promoted by the government in Sanjiang County via farmer subsidies, operations in dry fields distant from the village and on certain slopes was changed accordingly. The area of tea plantations continues to increase, particularly on dry field terrain. 
(a)

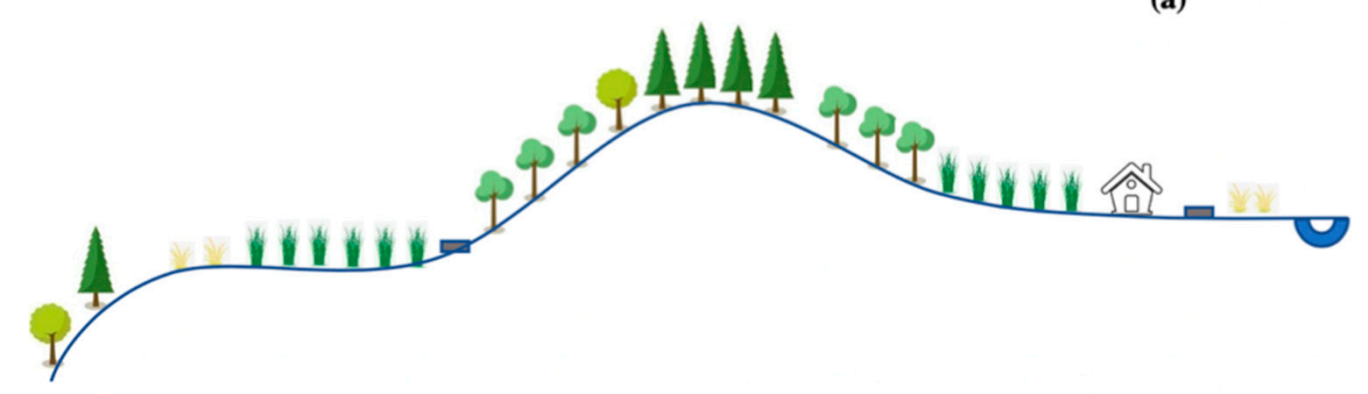

(b)

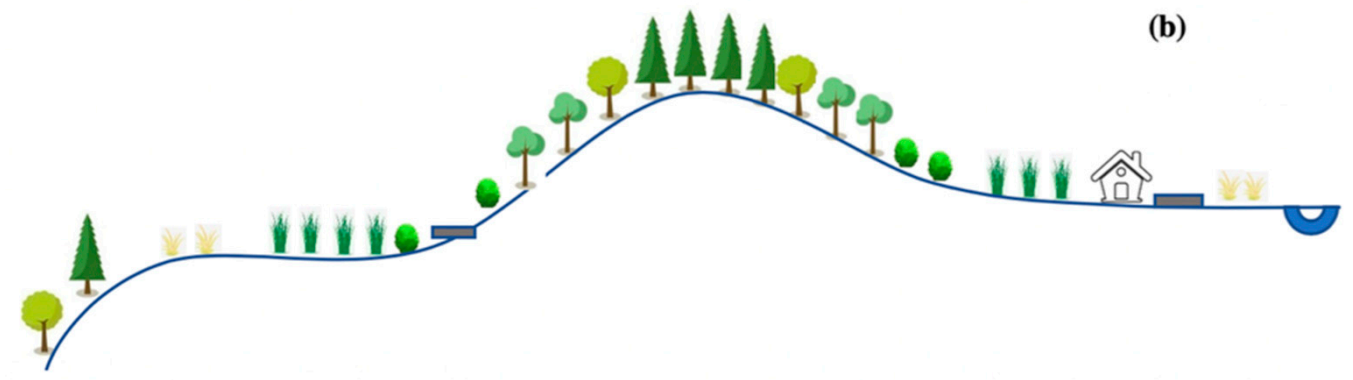

(c)
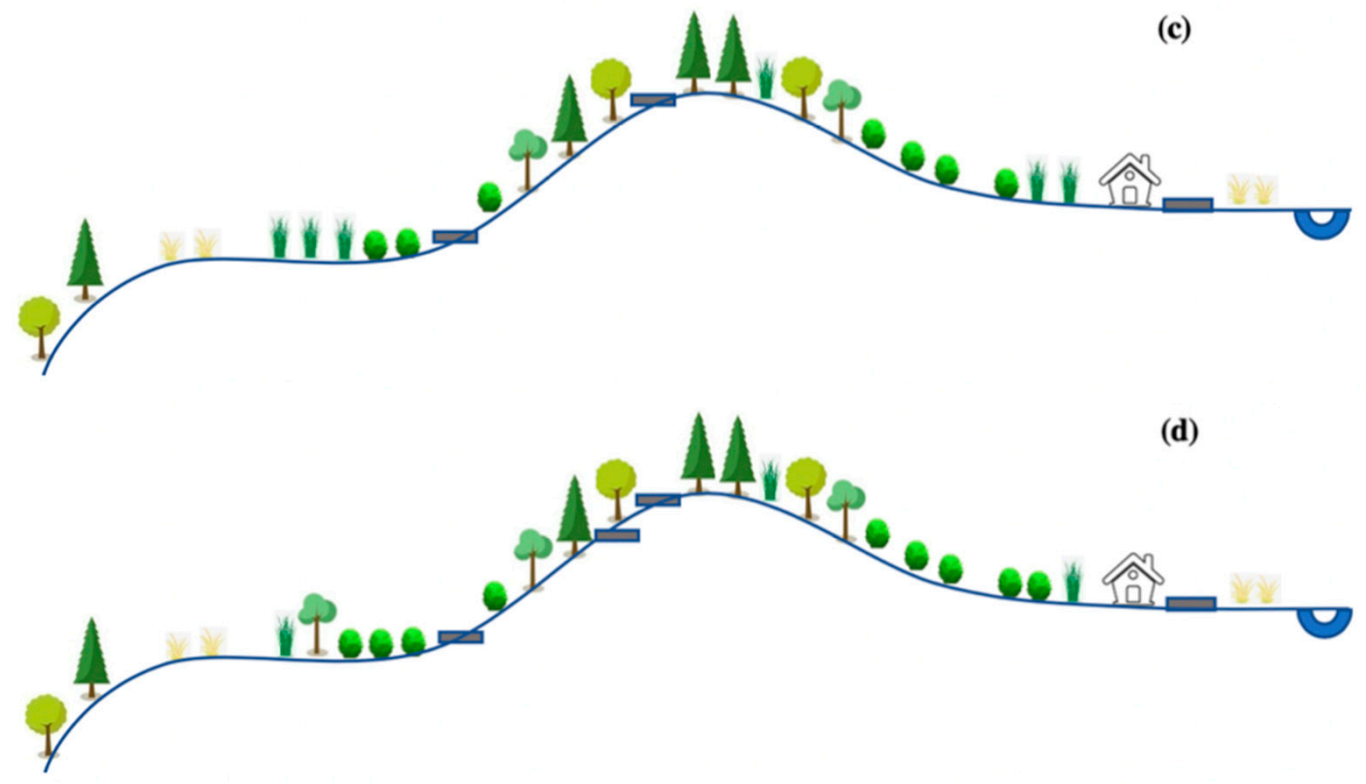

Legends

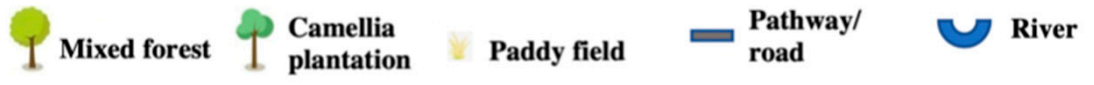

Fir

plantation

Tea
plantation

Dry field

Settlement

Figure 11. Transect models of land-use change: (a) around 1990; (b) 2009; (c) 2019; (d) 2020.

4.2. Backgrounds of Rapid Land-Use Change

4.2.1. Clarification of Land-Use Change in Relation to Natural and Anthropogenic Variables

Results from this research indicate that environmental variables play an important role in land-use change. Land accessibility affected where changes occurred, and natural variables constrained the type of change. The relationship between land-use change and 
environmental variables has an association with local workforce aging, but residents remain hard-working and willing to adopt land-use changes along with related management. Environmental variables were limited to natural attributes and proxy attributes in this research due to lack of official socioeconomic data at the village level in the research area. Further research on the driving forces of land-use change in this area need to include more socioeconomic variables.

The official data of Table 9 provided the backgrounds of depopulation and the related land-use change. Since Sanjiang is near to the Pearl River Delta area in Guangdong province, in which metropolitan cities that receive large populations of migrant workers like Guangzhou and Shenzhen are located, many farmers from Sanjiang became migrant workers in the Pearl River Delta area. Although there is no official data showing the destinations of these migrant workers in Sanjiang, local administrators provided the information that 42,300 farmers from poor villages in Liuzhou became migrant workers in Guangdong Province in 2021. In response to the national policy of poverty alleviation, Liuzhou city is cooperating with Zhanjiang city in Guangdong Province to provide Liuzhou residents with working opportunities in Zhanjiang city. This policy may drive more Dong people in Sanjiang to become migrant workers in Guangdong Province. Past research on ethnic minority villages in southwest China shows that with limited economic opportunities in the villages, many ethnic minority people chose to become short-distance as well as long-distance migrant workers [36]. This phenomenon has driven the cropland decline in the villages [37] and the loss of cultural identity in the young generation of ethnic minority children born in the cities [38]. However, due to the "hukou" system (the household registration system) that prevents migrant workers from settling down in the urban areas, most of them who had entered the cities in search of working opportunities had no choice but to return to their villages when they became old [39], and the degraded cropland may not provide enough subsistence for the returned old labours in the villages, which requires future research.

Table 9. Percentage of migrant workers in the male population, female population, and the whole population in Sanjiang County.

\begin{tabular}{cccc}
\hline Year & Male (\%) & Female (\%) & Whole Population (\%) \\
\hline 1990 & 0 & 0 & 0 \\
2000 & 11.17 & 10.66 & 10.93 \\
2010 & 26.53 & 22.14 & 24.46 \\
\hline
\end{tabular}

Data source: Provided by Liuzhou Agricultural and Rural Bureau.

The official land-use map of Gaoyou that is used in the village's developing plan for 2020-2035 provided by the local government shows different land-use types from our results. A large area is marked as dry field for rice cultivation in the official land-use map of 2020, but our results show that the dry field has been changed into a tea plantation in 2019. Our results are derived from field observations and drone imagery, indicating that the official land-use information is inaccurate. Since dry fields for rice cultivation like this is considered as 'Red line' farmland to staple grain crops, neglecting its land-use change may impose a risk on food security. Accordingly, land-use monitoring based on remote sensing techniques is required in the area to support adequate food supplies.

\subsubsection{Role of Policy Intervention in Land-Use Change}

Policy intervention brought land-use change into Gaoyou by introducing new landuses by means of reforms in the rural land system [20] and by providing subsidies for those crops favored by the government. Past research highlighted the importance of subsidy intervention on land use change [40-43]. Local government promotion has prompted the development of tea and camellia plantations in recent years, which can be seen in Figure 6. Figure 12 shows images of the same area. In Figure 12a the large area of dark green color with starlike texture indicates that there were fir plantations in this area in 2009. Although the area was cleared in 2019 for potential tea plantation (Figure 12b), the 2020 data show 
plantation with camellia seedlings (Figure 12c). This demonstrates farmers' quick response in relation to government subsidies and indicates the high importance of such in local land management regimes. Accordingly, governmental long-term plans in landscape planning and policy making are expected to be beneficial.

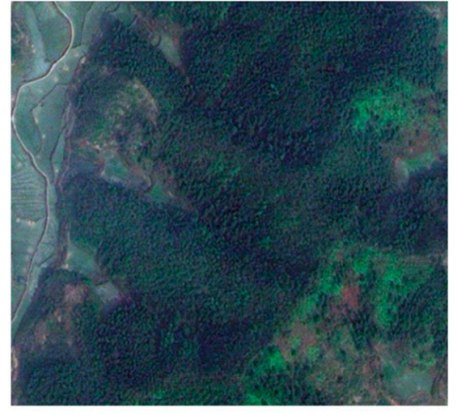

(a)

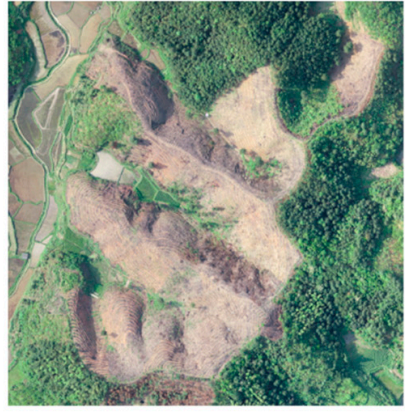

(b)

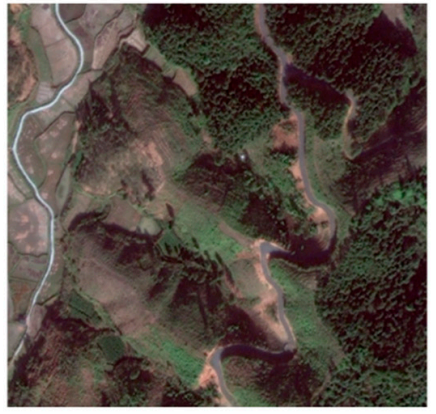

(c)

Figure 12. Rapid land-use changes in the same area. (a) Fir plantation (2009) (b) Barren land (2019) (c) Camellia plantation (2020).

Figure 13 shows how increased road area and length are causing forest fragmentation. Local administrators have increased road presence via tourism-related construction in Sanjiang and local government funding to relieve poverty in the area. Interviews with local administrators from the Liuzhou Agricultural and Rural Bureau and Sanjiang Agricultural Bureau provided the explanation that there is a lack of overall planning for the use of poverty alleviation funds because the settlement and local farmland/forests are managed by different administrations [44], but road construction is seen as the most efficient route to poverty alleviation regardless of the administrative body [45,46]. It is evident that roads support agricultural profit by providing routes to markets, and the large area of bamboo plantation from field observation in our research is an example of the failure of the problematic promotion of agricultural products and the poor transportation linked to the only bamboo manufactory in Sanjiang, in which the bamboo went moldy in the producing area, as is pointed out by the local administrators. There is also a lack of planning for road construction; administrations simply launch a tender process to secure contractors, who themselves decide where to build new roads, resulting in the rapid road growth within the village and non-sufficient roads that connect the producing areas, manufactories and market [47]. In order to promote tourism in the Gaoyou village, the Sanjiang government has decided to expand the width of roads so that more automobiles can come into the village. Results from Table 8 demonstrated that the road construction work in Gaoyou not only fragmented the forest where new road was built, but also caused land-use changes along the old road. The authors' result shows that the road was built on relatively steep slopes in Gaoyou. During the study's field survey, landslides onto roads were observed due to a lack of maintenance funding. Accordingly, it is advisable for different administrations to collaborate with ecological experts on village development plans. 


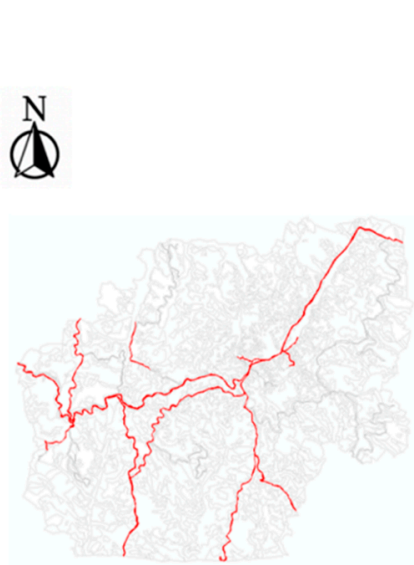

(a)

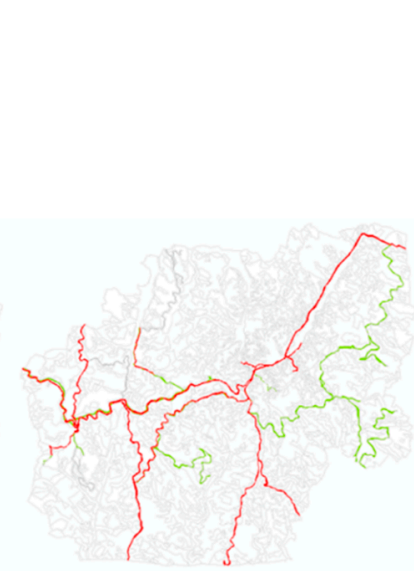

(b)

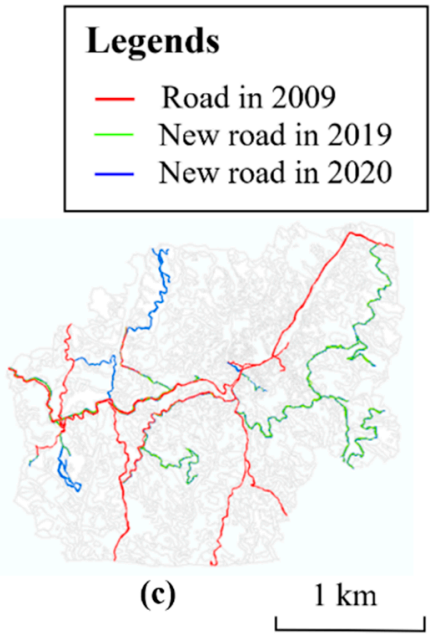

Figure 13. Road changes in (a) 2009, (b) 2019 and (c) 2020.

\subsubsection{Role of Local Dong People's Traditional Ecological Knowledge}

Previous research emphasized the potential contribution of traditional ecological knowledge in conserving biodiversity [48] and making sustainable resource management plans [49]. Japan launched the Satoyama Initiative in 2010 to realize "societies in harmony with nature" through landscape approaches to arouse interest in biodiversity and ecosystem conservation and to rebuild a healthy human-nature relationship [50]. It highlighted the importance of traditional ecological knowledge in case studies both in Japan and internationally [44,50-55]. Research on rural landscapes adopting traditional ecological knowledge across the globe can provide models for making sustainable management plans. The research result demonstrates the potential of using Gaoyou village as a model for making sustainable resource management plans if the landscape and the related natural resources management regimes including land resource management are well preserved. The three aspects of traditional ecological knowledge: the knowledge system, the system of practice, and the moral and spiritual values, was identified [48].

As for system of practice, the authors' previous research indicated favorable landscape preservation in Gaoyou [20]. The research reported here suggested efficient use of local land resources despite extensive abandonment of farmland in mountainous areas of southwestern China [56]. Gaoyou farmers reported almost no land abandonment in the village; in the absence of young labor to manage farmland distant from the village, farmers tend to grow tea or firs rather than abandoning cultivation areas. Fir trees are highly valued in Dong culture, providing lumber and materials for construction and everyday living as well as having particular spiritual significance [57]. The authors' research showed that most fir plantations were not changed to allow other forms of land use. Residents also reported logging only for local construction rather than for commercial purposes, as well as immediate replanting of fir saplings for replenishment. Firs are also planted in dry fields distant from the village and from roads. There are some collective fir plantations in the village, from which the timber was used for the construction and repair of public structures such as the Fengyu Bridge and Drum Tower. Residents also contribute timber from their own forest area if there is not enough timber for public structures. Fir trees thus play an essential communal role in Dong culture.

It is worth pointing out that during the field observations and interviews with local farmers, many migrant short-distance workers are observed in Gaoyou. Due to the Dong people's traditional ecological knowledge in moral and spiritual values, the landscape forest is preserved in every Dong village where bio-resources are conserved. And many Dong farmers return to the village to participate in discussions concerning the future development plans of the village, to help with villagers' house construction work, and to conduct major agricultural activities like rice cultivation and logging in the fir plantations. 
The research indicates a need for further research on the relationship between ethnic culture and constant land use without change.

Local tourism is developing due to Gaoyou's status of preservation on UNESCO's Tentative List for Cultural Heritage, and the favorable development of tea plantations and local crops such as sweet potatoes and leeks supports local livelihoods. Tourism in other Dong villages tends to be managed by external commercial operators, while that in Gaoyou is more promoted by residents. The area's relatively developed agricultural cooperatives and infrastructures may contribute to the efficient use of local land resources, and policymakers may view Gaoyou as a good example for rural revival and focus on the wellbeing of local farmers to ensure a fair income from tourism and sufficient livelihoods.

\subsection{Possible Loss in Ecosystem Services Due to Rapid Land-Use Change}

Due to lack of data to evaluate the ecosystem services changes in this research, we would like to point out some possible loss in ecosystem services that are observed in this research, hoping to shed light on future research in this area. Past research revealed that the abandonment of agricultural land may induce loss in ecosystem services, especially in biodiversity loss [58]. Field observations found that some unmanaged dry fields turned into barren land with scattered vegetation, and a possible explanation for this is that Gaoyou is located in a mountainous area, where farmland reclamation may cause land degradation $[59,60]$. Although roads support agricultural profit by providing routes to markets, their construction causes landscape fragmentation and represents land-use change, potentially causing significant ecological downsides [61-63]. Results of changes in landscape patterns shows that there is a trend of monoculture toward tea plantations in Gaoyou. Therefore, further environmental assessment for the area is required.

\section{Conclusions}

This research identified that there is rapid land use change in a Dong ethnic minority village in southwest China. During 2009 and 2019, when tea plantations started to be widely promoted in Sanjiang, the landscape in Gaoyou became fragmented and more diverse, while between 2019 and 2020 the continuously increasing tea plantations and camellia plantation combined the detached patches and created a larger monoculture area, thereby reducing landscape diversity. Environmental variables of land accessibility affected where the changes occurred, and natural variables constrained the type of change. Policy interventions like subsidies influenced farmers' decisions on land-use. Issues in land-use like extensive road construction were observed. Although the results revealed an aging workforce in Gaoyou, the land resources were still efficiently used by the local Dong farmers.

Our research demonstrates the potential of integrated analysis of land use change, landscape pattern analysis and multivariate analysis in studying rural land use change. For instance, analysis of area change in each land-use type gives the simple result that there is rapid land-use change in Gaoyou, while the change in landscape metrics of landscape diversity and fragmentation shows that the introduction of new land uses may benefit the landscape pattern at the first stage, but will jeopardize it if there is a monocultural trend in the new land use.

There are deficiencies in this research. There is a limitation in the study period due to the available satellite imagery in this region. The resolutions of imagery data were different; therefore, an assumption that the paddy field remained unchanged was made, and the changes of the composition of mixed forests is also neglected. Furthermore, only natural and proxy variables were selected as environmental drivers due to the lack of some socioeconomic data at the village level.

We suggest more site-specific future research with a longer time span in this region, more evaluation of the impacts of environmental driving factors and assessment of ecosystem services, and research on the relationship between ethnic people's traditional ecological knowledge and land use change. We also suggest that different administrations should 
cooperate to make long-term regional development plans, and land use monitoring with remote sensing techniques is needed.

Author Contributions: Conceptualization, F.Q., K.F. and S.S.; Methodology, F.Q., K.F. and S.S.; Software, F.Q.; Validation, F.Q., K.F. and S.S.; Formal Analysis, F.Q.; Investigation, F.Q.; Resources, F.Q.; Data Curation, F.Q.; Writing-Original Draft Preparation, F.Q.; Writing-Review \& Editing, K.F. and S.S.; Visualization, F.Q.; Supervision, S.S.; Project Administration, S.S. All authors have read and agreed to the published version of the manuscript.

Funding: This research received no external funding.

Institutional Review Board Statement: Not applicable.

Informed Consent Statement: Not applicable.

Data Availability Statement: The data presented in this study are available on request from the author.

Acknowledgments: We thank Xiaoping Liu, a deputy director of the Liuzhou Agricultural Bureau and a senior agronomist, for providing governmental data, statistic books and insightful comments on this paper.

Conflicts of Interest: The authors declare that they have no conflict of interest.

\section{References}

1. Foley, J.; Defries, R.; Asner, G.; Barford, C.; Bonan, G.; Carpenter, S.; Chapin, F.; Coe, M.; Daily, G.; Gibbs, H.; et al. Global consequences of land use. Science 2005, 309, 570-574. [CrossRef] [PubMed]

2. $\quad$ Lambin, E.F.; Baulies, X.; Bockstael, N.; Fischer, G.; Krug, T.; Leemans, R.; Moran, E.; Rindfuss, R.; Sato, Y.; Skole, D.; et al. Land-Use and Land-Cover Change (LUCC): Implementation Strategy. A Core Project of the International Geosphere-Biosphere Programme and the International Human Dimensions Programme on Global Environmental Change; IGBP Report 48, IHDP Report 10; IGBP: Stockholm, Sweden, 1999; Volume 125.

3. Long, H.; Zhang, Y.; Ma, L.; Tu, S. Land Use Transitions: Progress, Challenges and Prospects. Land 2021, 10, 903. [CrossRef]

4. Newbold, T.; Hudson, L.N.; Hill, S.L.; Contu, S.; Lysenko, I.; Senior, R.A.; Börger, L.; Bennett, D.J.; Choimes, A.; Collen, B.; et al. Global effects of land use on local terrestrial biodiversity. Nature 2015, 520, 45-50. [CrossRef]

5. $\quad$ Bugalho, M.; Caldeira, M.; Pereira, J.; Aronson, J.; Pausas, J. Mediterranean cork oak savannas require human use to sustain biodiversity and ecosystem services. Front. Ecol. Environ. 2011, 9, 278-286. [CrossRef]

6. Weng, Q. Land use change analysis in the Zhujiang Delta of China using satellite remote sensing, GIS and stochastic modelling. J. Environ. Manag. 2002, 64, 273-284. [CrossRef] [PubMed]

7. Liu, J.; Zhang, Z.; Xu, X.; Kuang, W.; Zhou, W.; Zhang, S.; Li, R.; Yan, C.; Yu, D.; Wu, S.; et al. Spatial patterns and driving forces of land use change in China during the early 21st century. J. Geogr. Sci. 2010, 20, 483-494. [CrossRef]

8. Liu, J.; Liu, M.; Zhuang, D.; Zhang, Z.; Deng, X. Study on spatial pattern of land-use change in China during 1995-2000. Sci. China Ser. D Earth Sci. 2003, 46, 373-384. [CrossRef]

9. Peng, J.; Wu, J.; Yin, H.; Li, Z.; Chang, Q.; Mu, T. Rural Land Use Change during 1986-2002 in Lijiang, China, Based on Remote Sensing and GIS Data. Sensors 2008, 8, 8201-8223. [CrossRef]

10. Long, H.; Tu, S.; Ge, D.; Li, T.; Liu, Y. The allocation and management of critical resources in rural China under restructuring: Problems and prospects. J. Rural Stud. 2016, 47, 392-412. [CrossRef]

11. Su, Y.; Qian, K.; Lin, L.; Wang, K.; Guan, T.; Gan, M. Identifying the driving forces of non-grain production expansion in rural China and its implications for policies on cultivated land protection. Land Use Policy 2020, 92, 104435. [CrossRef]

12. Vitousek, P.; Mooney, H.; Lubchenco, J.; Melillo, J. Human Domination of Earth's Ecosystems. Science 1997, $277,494-499$. [CrossRef]

13. Dadashpoor, H.; Azizi, P.; Moghadasi, M. Land use change, urbanization, and change in landscape pattern in a metropolitan area. Sci. Total Environ. 2019, 655, 707-719. [CrossRef] [PubMed]

14. Liu, J.; Kuang, W.; Zhang, Z.; Xu, X.; Qin, Y.; Ning, J.; Zhou, W.; Zhang, S.; Li, R.; Yan, C.; et al. Spatiotemporal characteristics, patterns, and causes of land-use changes in China since the late 1980s. J. Geogr. Sci. 2014, 24, 195-210. [CrossRef]

15. Tang, J.; Li, Y.; Cui, S.; Xu, L.; Ding, S. Linking land-use change, landscape patterns, and ecosystem services in a coastal watershed of southeastern China. Glob. Ecol. Conserv. 2020, 23, e01177. [CrossRef]

16. Bürgi, M.; Hersperger, A.M.; Schneeberger, N. Driving forces of landscape change-current and new directions. Landsc. Ecol. 2004, 19, 857-868. [CrossRef]

17. Lambin, E.; Geist, H.; Lepers, E. Dynamics of Land-Use and Land-Cover Change in Tropical Regions. Annu. Rev. Environ. Resour. 2003, 28, 205-241. [CrossRef]

18. Gómez-Baggethun, E.; Corbera, E.; Reyes-García, V. Traditional Ecological Knowledge and Global Environmental Change: Research findings and policy implications. Ecol. Soc. 2013, 18, 72. [CrossRef] 
19. Yan, H.; Ku, H.; Xu, S. Rural revitalization, scholars, and the dynamics of the collective future in China. J. Peasant Stud. 2021, 48, 853-874. [CrossRef]

20. Qin, F.; Fukamachi, K.; Shibata, S. Changes in indigenous natural resource utilisation regimes in a Dong ethnic minority village in southwest China. Landsc. Ecol. Eng. 2021, 17, 323-337. [CrossRef]

21. Gray, P.; Ridge, J.; Poulin, S.; Seymour, A.; Schwantes, A.; Swenson, J.; Johnston, D. Integrating Drone Imagery into High-resolution Satellite Remote Sensing Assessments of Estuarine Environments. Remote Sens. 2018, 10, 1257. [CrossRef]

22. Yao, H.; Qin, R.; Chen, X. Unmanned Aerial Vehicle for Remote Sensing Applications-A Review. Remote Sens. 2019, 11, 1443. [CrossRef]

23. Rango, A.; Laliberte, A.; Herrick, J.; Winters, C.; Havstad, K.; Steele, C.; Browning, D. Unmanned aerial vehicle-based remote sensing for rangeland assessment, monitoring, and management. J. Appl. Remote Sens. 2009, 3, 033542. [CrossRef]

24. Zhu, J.; Sun, K.; Jia, S.; Li, Q.; Hou, X.; Lin, W.; Liu, B.; Qiu, G. Urban Traffic Density Estimation Based on Ultrahigh-Resolution UAV Video and Deep Neural Network. IEEE J. Sel. Top. Appl. Earth Obs. Remote Sens. 2018, 11, 4968-4981. [CrossRef]

25. Gioia, D.; Amodio, A.; Maggio, A.; Sabia, C. Impact of Land Use Changes on the Erosion Processes of a Degraded Rural Landscape: An Analysis Based on High-Resolution DEMs, Historical Images, and Soil Erosion Models. Land 2021, 10, 673. [CrossRef]

26. McGarigal, K. Fragstats Help. 2015. Available online: https://ibis.geog.ubc.ca/courses/geob479/labs/fragstats.help.4.pdf (accessed on 22 February 2022).

27. Li, H.; Wu, J. Use and misuse of landscape indices. Landsc. Ecol. 2004, 19, 389-399. [CrossRef]

28. Cushman, S.A.; McGarigal, K.; Neel, M.C. Parsimony in landscape metrics: Strength, universality, and consistency. Ecol. Indic. 2008, 8, 691-703. [CrossRef]

29. Southworth, J.; Nagendra, H.; Tucker, C. Fragmentation of a Landscape: Incorporating landscape metrics into satellite analyses of land-cover change. Landsc. Res. 2002, 27, 253-269. [CrossRef]

30. UNESCO. Dong Villages. 2013. Available online: http://whc.unesco.org/en/tentativelists/5813/ (accessed on 24 December 2020).

31. Uuemaa, E.; Antrop, M.; Roosaare, J.; Marja, R.; Mander, Ü. Landscape Metrics and Indices: An Overview of Their Use in Landscape Research. Living Rev. Landsc. Res. 2009, 3, 1-28. [CrossRef]

32. Mertens, B.; Lambin, E. Land-cover-change trajectories in southern Cameroon. Ann. Am. Assoc. Geogr. 2000, 90, 467-494. [CrossRef]

33. Hietel, E.; Waldhardt, R.; Otte, A. Linking socio-economic factors, environment and land cover in the German Highlands, 1945-1999. J. Environ. Manag. 2005, 75, 133-143. [CrossRef]

34. Kong, W.; Sun, O.J.; Chen, Y.; Yu, Y.; Tian, Z. Patch-level based vegetation change and environmental drivers in Tarim River drainage area of West China. Landsc. Ecol. 2010, 25, 1447-1455. [CrossRef]

35. Hietel, E.; Waldhardt, R.; Otte, A. Analysing land-cover changes in relation to environmental variables in Hesse, Germany. Landsc. Ecol. 2004, 19, 473-489. [CrossRef]

36. Gustafsson, B.; Sai, D. Villages Where China's Ethnic Minorities Live. China Econ. Rev. 2006, 20, 193-207. [CrossRef]

37. Yu, Y.; Xu, T.; Wang, T. Outmigration Drives Cropland Decline and Woodland Increase in Rural Regions of Southwest China. Land 2020, 9, 443. [CrossRef]

38. Geary, D.; Pan, Y. A Bilingual Education Pilot Project among the Kam People in Guizhou Province, China. J. Multiling. Multicult. Dev. 2003, 24, 274-289. [CrossRef]

39. Cheng, T.; Selden, M. The Origins and Social Consequences of China's Hukou System. China Q. 1994, 139, 644-668. [CrossRef]

40. Lambin, E.; Turner, B.; Geist, H.; Agbola, S.; Angelsen, A.; Bruce, J.; Coomes, O.; Dirzo, R.; Fischer, G.; Folke, C.; et al. The causes of land-use and land-cover change: Moving beyond the myths. Glob. Environ. Chang. 2001, 11, 261-269. [CrossRef]

41. Lubowski, R.; Bucholtz, S.; Claassen, R.; Roberts, M.; Cooper, J.; Gueorguieva, A.; Johansson, R. Environmental Effects of Agricultural Land-Use Change: The Role of Economics and Policy; Economic Research Report 33591; United States Department of Agriculture, Economic Research Service: Washington, DC, USA, 2006.

42. Jiang, L.; Deng, X.; Seto, K. The impact of urban expansion on agricultural land use intensity in China. Land Use Policy 2013, 35, 33-39. [CrossRef]

43. Keys, E.; McConnell, W. Global change and the intensification of agriculture in the tropics. Glob. Environ. Chang. 2005, 15, 320-337. [CrossRef]

44. Wang, J.; Xu, J. The ecological connotation of Japan's "satoyama initiative" and its practical dilemma in China's Ethnic areas-A case study in Balong Village, Lengshui Town, Shizhu Tujia Autonomous County, Chongqing Municipality. J. MUC (Nat. Sci. Ed.) 2019, 28, 5-14. (In Chinese)

45. Park, A.; Wang, S. Community-based development and poverty alleviation: An evaluation of China's poor village investment program. J. Public Econ. 2010, 94, 790-799. [CrossRef]

46. Li, Y.; Su, B.; Liu, Y. Realizing targeted poverty alleviation in China. China Agric. Econ. Rev. 2016, 8, 443-454. [CrossRef]

47. Shukla, M.; Jharkharia, S. Agri-fresh produce supply chain management: A state-of-the-art literature review. Int. J. Oper. Prod. Manag. 2013, 33, 114-158. [CrossRef]

48. Berkes, F.; Folke, C.; Gadgil, M. Traditional Ecological Knowledge, Biodiversity, Resilience and Sustainability. In Biodiversity Conservation. Ecology, Economy E Environment; Perrings, C.A., Mäler, K.G., Folke, C., Holling, C.S., Jansson, B.O., Eds.; Springer: Dordrecht, The Netherlands, 1995; Volume 4. [CrossRef] 
49. Kumar, A.; Kumar, S.; Komal; Ramchiary, N.; Singh, P. Role of Traditional Ethnobotanical Knowledge and Indigenous Communities in Achieving Sustainable Development Goals. Sustainability 2021, 13, 3062. [CrossRef]

50. Takeuchi, K. Rebuilding the relationship between people and nature: The Satoyama Initiative. Ecol. Res. 2010, 25, 891-897. [CrossRef]

51. Fukamachi, K.; Oku, H.; Nakashizuka, T. The change of a satoyama landscape and its causality in Kamiseya, Kyoto Prefecture, Japan between 1970 and 1995. Landsc. Ecol. 2001, 16, 703-717. [CrossRef]

52. Berglund, B.E.; Kitagawa, J.; Lagerås, P.; Nakamura, K.; Sasaki, N.; Yasuda, Y. Traditional Farming Landscapes for Sustainable Living in Scandinavia and Japan: Global Revival Through the Satoyama Initiative. AMBIO 2014, 43, 559-578. [CrossRef]

53. Dublin, D.R.; Tanaka, N. Indigenous agricultural development for sustainability and "satoyama". Geogr. Environ. Sustain. 2014, 7, 86-95. [CrossRef]

54. Saito, O.; Subramanian, S.M.; Hashimoto, S.; Takeuchi, K. Introduction: Socio-ecological production landscapes and seascapes. In Managing Socio-Ecological Production Landscapes and Seascapes for Sustainable Communities in Asia; Saito, O., Subramanian, S., Hashimoto, S., Takeuchi, K., Eds.; Science for Sustainable Societies; Springer: Singapore, 2020.

55. Mohri, H.; Lahoti, S.; Saito, O.; Mahalingam, A.; Gunatilleke, N.; Irham; Van Thang, H.; Hitinayake, G.; Takeuchi, K.; Herath, S. Assessment of ecosystem services in homegarden systems in Indonesia, Sri Lanka, and Vietnam. Ecosyst. Serv. 2013, 5, 124-136. [CrossRef]

56. Shi, T.; Li, X.; Xin, L.; Xu, X. Analysis of Farmland Abandonment at Parcel Level: A Case Study in the Mountainous Area of China. Sustainability 2016, 8, 988. [CrossRef]

57. $\mathrm{Gu}, \mathrm{K}$. Analyses on Folklore of Eighteen Years Old Chinese Fir from the View of Ecosystem Culture. J. Beijing For. Univ. (Soc. Sci.) 2007, 6, 1-15.

58. Benayas, J. Abandonment of agricultural land: An overview of drivers and consequences. CAB Rev. Perspect. Agric. Vet. Sci. Nutr. Nat. Resour. 2007, 2,1-14. [CrossRef]

59. Wang, S.; Liu, Q.; Zhang, D. Karst rocky desertification in southwestern China: Geomorphology, landuse, impact and rehabilitation. Land Degrad. Dev. 2004, 15, 115-121. [CrossRef]

60. Eckholm, E. The Deterioration of Mountain Environments. Science 1975, 189, 764-770. [CrossRef] [PubMed]

61. Jaarsma, C.F.; Willems, G.P.A. Reducing habitat fragmentation by minor rural roads through traffic calming. Landsc. Urban Plan. 2002, 58, 125-135. [CrossRef]

62. Li, T.; Shilling, F.; Thorne, J.; Li, F.; Schott, H.; Boynton, R.; Berry, A.M. Fragmentation of China's landscape by roads and urban areas. Landsc. Ecol. 2010, 25, 839-853. [CrossRef]

63. Fu, W.; Liu, S.; Degloria, S.; Dong, S.; Beazley, R. Characterizing the "fragmentation-barrier" effect of road networks on landscape connectivity: A case study in Xishuangbanna, Southwest China. Landsc. Urban Plan. 2010, 95, 122-129. [CrossRef] 